\title{
De officier van justitie
}

Citation for published version (APA):

Simmelink, J. (2015). De officier van justitie: magistraat in een bestuursorgaan. Maastricht University. https://doi.org/10.26481/spe.20161030js

Document status and date:

Published: 30/10/2015

DOI:

10.26481/spe.20161030js

Document Version:

Publisher's PDF, also known as Version of record

Document license:

Unspecified

\section{Please check the document version of this publication:}

- A submitted manuscript is the version of the article upon submission and before peer-review. There can be important differences between the submitted version and the official published version of record.

People interested in the research are advised to contact the author for the final version of the publication, or visit the DOI to the publisher's website.

- The final author version and the galley proof are versions of the publication after peer review.

- The final published version features the final layout of the paper including the volume, issue and page numbers.

Link to publication

\footnotetext{
General rights rights.

- You may freely distribute the URL identifying the publication in the public portal. please follow below link for the End User Agreement:

www.umlib.nl/taverne-license

Take down policy

If you believe that this document breaches copyright please contact us at:

repository@maastrichtuniversity.nl

providing details and we will investigate your claim.
}

Copyright and moral rights for the publications made accessible in the public portal are retained by the authors and/or other copyright owners and it is a condition of accessing publications that users recognise and abide by the legal requirements associated with these

- Users may download and print one copy of any publication from the public portal for the purpose of private study or research.

- You may not further distribute the material or use it for any profit-making activity or commercial gain

If the publication is distributed under the terms of Article $25 \mathrm{fa}$ of the Dutch Copyright Act, indicated by the "Taverne" license above, 
J.B.H.M. Simmelink

Faculteit der Rechtsgeleerdheid

Officier van justitie: magistraat in een bestuursorgaan 


\section{Officier van justitie: magistraat in een bestuursorgaan}

J.B.H.M. Simmelink 


\section{Colofon}

Design \& print: Canon Business Services, Maastricht

ISBN: 9789056814632

NUR: 824

All rights reserved. No part of this publication may be reproduced, modified, stored in a retrieval system or made public without the prior written permission of the author or publisher. 


\title{
Officier van justitie: magistraat in een bestuursorgaan
}

\author{
Rede \\ uitgesproken bij de aanvaarding van het ambt \\ van bijzonder hoogleraar Openbaar Ministerie \\ aan de Faculteit der Rechtsgeleerdheid van de \\ Universiteit Maastricht
}

op vrijdag 30 oktober 2015

door

J.B.H.M. Simmelink 
Ter nagedachtenis aan mijn zusje Sandra en mijn lieve moeder 


\section{Officier van justitie: magistraat in een bestuursorgaan}

Mijnheer de rector, geachte aanwezigen,

\section{Inleiding}

Het kan voor $u$ geen verrassing zijn dat ik vandaag zal spreken over het Openbaar Ministerie. In de titel van mijn voordracht ligt besloten dat ik vandaag in wil gaan op twee voor het Openbaar Ministerie klassieke onderwerpen. Dat betreft de taak van het Openbaar Ministerie als organisatie tot strafrechtelijke handhaving van de rechtsorde en de taak van de officier van justitie als functionaris in het strafproces. ${ }^{1}$ De taak tot handhaving van de rechtsorde impliceert dat het Openbaar Ministerie heeft te waken over de rechtsstatelijkheid van de opsporing en vervolging. En de officier van justitie als functionaris moet zijn werkzaamheden verrichten met een magistratelijke attitude. Met deze thema's ga ik verder op het onderwerp waarover mijn voorganger op de bijzondere leerstoel Openbaar Ministerie, Paul Frielink, op 18 september 2009 vanaf deze plaats heeft gesproken. Zijn rede, getiteld 'Het OM: schakel in een geloofwaardige strafrechtspleging', ${ }^{2}$ stond in het teken van zorg over het draagvlak van de strafrechtspleging in de samenleving. De centrale rol in de strafrechtspleging stelt het Openbaar Ministerie in staat om een belangrijke bijdrage te leveren aan versteviging van dat maatschappelijk draagvlak. Randvoorwaarde hiervoor is dat mag worden vertrouwd op de kwaliteit van het werk van het Openbaar Ministerie en het adequaat functioneren van de organisatie. Voor versteviging van dat vertrouwen formuleerde Frielink verschillende aandachtspunten. Dat was op de eerste plaats de kwaliteit van de strafrechtelijke interventie. Hierbij gaat het om de selectie van zaken die wel of niet strafrechtelijk moeten worden afgedaan en om de snelheid, betrouwbaarheid en effectiviteit van de interventie. Het tweede aandachtspunt betreft de kwaliteit van de organisatie van het Openbaar Ministerie. Het Openbaar Ministerie moet zijn organisatie zo hebben ingericht, dat 'de professionele kwaliteit duurzaam is geborgd'. 3 Het derde aandachtspunt ziet op de relaties van het Openbaar Ministerie.

1 Gemakshalve gebruik ik in de tekst alleen de aanduiding 'officier van justitie'. Voor alle duidelijkheid: hieronder moet de advocaat-generaal van het ressortsparket worden begrepen.

2 Sdu Uitgevers: Den Haag 2010.

3 Frielink, a.w. (2010), p. 9. 
In het samenspel tussen de zittende magistratuur, de advocatuur, de politie en het Openbaar Ministerie zou men op elkaar moeten kunnen vertrouwen, waarbij de basis voor vertrouwen in het doen en laten van het Openbaar Ministerie berust op zijn oriëntatie op wet en recht. Kwaliteit van werk en organisatie en de rechtstatelijke oriëntatie zijn de komende drie kwartier regelmatig terugkerende thema's.

De laatste jaren is er vanuit verschillende richtingen kritiek geleverd op het werk en het functioneren van het Openbaar Ministerie. In grote lijnen en wat vrij weergegeven is de slotsom van deze kritiek dat het Openbaar Ministerie een zwakke schakel zou zijn in een weinig geloofwaardige strafrechtspleging. Voorts zou het Openbaar Ministerie de taak om te waken over de rechtsstatelijkheid van de strafvordering verwaarlozen en het optreden van de officier van justitie in concrete zaken zou onvoldoende getuigen van magistratelijkheid. Deels als reactie op deze kritiek en deels met het oog op reorganisatie zijn binnen het Openbaar Ministerie brede veranderingsprocessen ingezet. De inzet daarvan is dat de organisatie wordt gemoderniseerd en beter wordt toegerust voor de uitvoering van de vele aan haar opgedragen taken. Parallel aan deze veranderingen en ter versterking van de strafrechtspleging wordt gewerkt aan de modernisering van het Wetboek van Strafvordering. ${ }^{4}$ De dynamiek van kritiek, veranderingsprocessen en modernisering van de strafvorderlijke wetgeving hebben mij gebracht tot het onderwerp van deze openbare les.

Door de uiteenlopende veranderingen in de organisatie van de strafrechtspleging verkeert het Openbaar Ministerie thans in onrustig vaarwater. Hierdoor staan de van het Openbaar Ministerie verlangde rechtsstatelijke waakzaamheid en de magistratelijke attitude van de officier van justitie inderdaad onder druk. Deze waakzaamheid en attitude worden doorgaans beschouwd als belangrijke waarborgen in relatie tot de spilpositie van het Openbaar Ministerie en de officier

4 Zie over de modernisering van het Wetboek van Strafvordering de brief van de minister van V\&J van 30 september 2015, TK 29 279, nr. 278 met de zogenaamde Contourennota. 
van justitie in het strafproces. ${ }^{5}$ In het gemoderniseerde Wetboek van Strafvordering wordt deze spilpositie gehandhaafd. ${ }^{6}$ Dat is voor mij aanleiding om stil te staan bij de vraag wat de klassieke waarborgen voor een rechtmatige strafvordering voor de toekomst betekenen. ${ }^{7}$

\section{Het Openbaar Ministerie onder vuur}

Kritiek op het functioneren van het Openbaar Ministerie is niet slechts van recente datum. De organisatie ligt al veel langer onder de loep. ${ }^{8}$ Voor begrip van de kritiek die de laatste jaren op het Openbaar Ministerie wordt geleverd, is het voldoende terug te gaan naar een rapport van de Algemene Rekenkamer over 'Prestaties in de strafrechtsketen' uit 2012. ${ }^{9}$ Dit rapport bevat de resultaten van onderzoek door de ARK naar de in-, door- en uitstroom van strafzaken in de gehele strafrechtsketen, van politie via Openbaar Ministerie en rechter tot de fase van de tenuitvoerlegging. De overkoepelende conclusie is, kort gezegd, dat de strafrechtspleging als keten nogal gebrekkig functioneerde. ${ }^{10}$

5 Over de betekenis en consequenties van deze waarborgen zijn in de loop der decennia de nodige geschriften gepubliceerd. Zie voor een overzicht van de uitvoerige literatuur de bijdrage van H. van de Bunt en J. Beckers, 'De 'gruwel' van De Doelder. Enkele overpeinzingen over de positie van het Openbaar Ministerie ten opzichte van zijn minister', in: E. Bleichrodt e.a. (red.), Onbegrensd strafrecht, WLP: Nijmegen 2013, p. 285-308. Het is niet mijn bedoeling een schets te geven van de uit deze geschriften blijkende discussie of deze dunnetjes over te doen. Dat zou inhoudelijk slechts neerkomen op een herhaling van zetten. Zoals Witteveen heeft aangegeven, moeten de bedoelde discussies namelijk worden getypeerd als een 'debat zonder einde'; zie W.J. Witteveen, 'De minister en de officier: botsende rechtsstatelijke idealen', DD 1998, p.448-470.

6 Zie de Contourennota over de modernisering van het Wetboek van Strafvordering, TK 2015/16, 29 279, nr. 278, p. 6.

7 Met het betoog hoop ik een aanzet te geven voor de door Crijns, Ölcer en Schoep bepleite reflectie op de taak en positie van de officier van justitie; zie hun bijdrage 'De officier van justitie van de $21^{\text {ste }}$ eeuw. Taak en positie van de officier van justitie na de herijking van het Wetboek van Strafvordering', in: M.S. Groenhuijsen e.a. (red.), Roosachtig strafrecht, Kluwer: Deventer 2013, p. 141-165.

8 Vgl. M.E. de Meijer \& J.B.H.M. Simmelink, 'Het OM in de strafrechtsketen', in Het OM verandert, preadvies NVVS 2014, p. 134 e.v. Het rapport van 9 februari 2012 is opgenomen in TK 2011/12, 33 173, nr. 2.

10 Zie uitvoeriger M.S. Groenhuijsen, 'Consistentie en differentiatie: ondermaatse prestaties in de strafrechtsketen', DD 2012/44 
Het rapport maakte duidelijk dat er het nodige viel aan te merken op het Openbaar Ministerie. De kwaliteit van de strafrechtelijke interventie liet veel te wensen over, de organisatie was niet op orde en de regievoering door het Openbaar Ministerie over de werking van de strafrechtsketen was onvoldoende.

Naar aanleiding van het rapport van de ARK werd door de Minister van $V \& J$ ter verbetering van de werking van de strafrechtspleging het 'programma versterking van de prestaties in de strafrechtsketen' (verder VPS) geïntroduceerd. Het betreft een omvangrijk hervormingsprogramma met een hoog ambitieniveau. Belangrijke onderdelen van het programma zijn gericht op het inzichtelijk maken van de in-, door- en uitstroom van zaken in de strafrechtsketen, het terugdringen van de zogenaamde ongewenste uitstroom ${ }^{11}$, digitalisering van de strafrechtspleging en een verkorting van de doorlooptijden van strafzaken. ${ }^{12}$ Een belangrijke 'poot' in het programma is de modernisering van het Wetboek van Strafvordering. Een omvangrijk wetgevingsprogramma moet leiden tot een modernisering van het strafprocesrecht. ${ }^{13}$

De met VPS in gang gezette veranderingsprocessen laten het Openbaar Ministerie niet onberoerd. De verbetering van de regievoering over de strafrechtsketen, de versnelling van de afdoening van strafbare feiten en de digitalisering van de strafrechtspleging vragen stevige inspanningen en organisatorische veranderingen. Parallel hieraan, mede ingegeven door bezuinigingen, heeft het Openbaar Ministerie zelf reorganisatieprocessen in gang gezet. De inzet van deze veranderingsprocessen is een kwalitatief beter werkend Openbaar Ministerie. Maarveranderingsprocessen kosten tijd, energie en ca paciteit. En doorgaans heeft dat een negatieve weerslag op het functioneren van organisaties. Tegen deze achtergrond hebben verschillende auteurs kritiek geuit op de wijze waarop het Openbaar Ministerie in de vele veranderingen uitvoering geeft aan de strafrechtelijke rechtshandhaving. Er bestaat zorg over de kwaliteit van het werk van het Openbaar Ministerie en het functioneren van de organisatie. Diverse kritieken zijn

11 Hiermee wordt gedoeld op het uitblijven van een strafrechtelijke reactie als gevolg van fricties tussen de schakels van de strafrechtsketen.

12 De inhoud van VPS laat zich kennen aan de hand van verschillende kamerstukken. Het belangrijkste is TK 2012/13, 27279 (rechtsstaat en rechtsorde), nr. 165. Zie daarnaast de nrs. 147, 156, 177, 204 en 215. Nader over VPS: De Meijer \& Simmelink, a.w. (2014), p. 162-167.

13 Zie over het wetgevingsproject B.F. Keulen, 'Wetboek op stelten. Over de modernisering van het Wetboek van Strafvordering', RM Themis 2014-5, p. 211-222. 
bepaald niet mals en soms nogal fundamenteel van aard. Zo heeft Mevis stevige woorden gebruikt ter karakterisering van het beleid van het Openbaar Ministerie in relatie tot de zogenaamde ZSM-werkwijze. ${ }^{1 / 115}$ Met deze term wordt gedoeld op de werkprocessen die zijn ontwikkeld voor versnelling van de afdoening door het Openbaar Ministerie van veel voorkomende criminaliteit. De woorden van Mevis overstijgen echter het kader van de ZSM-werkwijze en raken aan de algemene taakuitoefening door het Openbaar Ministerie. Mevis spreekt over 'een op de politiek gerichte inhoud van het OM-beleid waarin materieel - in zijn algemeenheid - weinig te merken is van een rechtsstatelijk of anderszins gefundeerde inhoudelijke oriëntatie of rechtsstatelijke waakzaamheid van het $\mathrm{OM}$, zulks als een nadrukkelijk beleden en zichtbaar tegenwicht tegen minister en politiek en gebaseerd op een voldoende zelfstandige machtsverhouding ten opzichte van de minister en de politiek'. Kort en bondig: het Openbaar Ministerie laat in het dagelijkse werk een tekort aan 'rechtsstatelijke waakzaamheid' zien en het Openbaar Ministerie laat zich teveel meevoeren aan de leiband van de minister van V\&J. ${ }^{16}$ Commentaar van dezelfde strekking klinkt door in woorden van Franken naar aanleiding van zijn vaststelling dat het Openbaar Ministerie heeft afgezien van het uitbrengen van advies over conceptwetsvoorstellen met betrekking tot de eigen bijdragen van veroordeelden aan de kosten van strafvordering en de kosten van detentie. Hij vraagt zich - voetnootsgewijs, doch niet minder belangrijk - af of zijn vaststelling voor het Openbaar Ministerie 'niet een duidelijke illustratie (is) van zijn positionering als ambtelijke buitendienst van het departement van Veiligheid \& Justitie' en of 'we ... daarom niet eens afscheid moeten nemen van het beeld dat de vertegenwoordigers van dit bestuursorgaan magistraten zijn?' ${ }^{17}$

14 Nader over deze werkwijze: G.C. Haverkate, 'ZSM: de huidige stand van zaken vanuit OMperspectief', DD 2015/23.

15 De afkorting 'ZSM' heeft een interessante ontwikkeling doorgemaakt. Oorspronkelijk stond de afkorting voor 'zo spoedig mogelijk', al snel uitgebreid tot 'zo selectief, snel, samen, slim, simpel en samenlevingsgericht mogelijk'. Tegenwoordig staan de drie letters voor 'zorgvuldig, snel en op maat'; zie hiervoor Jaarbericht Openbaar Ministerie 2014, p. 63.

16 P.A.M. Mevis, Versnelde afdoening in het strafrecht/ZSM: buitengewoon, buiten, gewoon; tijd voor reflectie en voor een ZSM-blik op berechting door de versnellende rechter', DD 2015/22, p. 221.

17 A.A. Franken, 'De kosten van de strafvordering en de kosten van detentie', DD 2015/42, p. 433 , voetnoot 25 . 
De signalen van Mevis en Franken kunnen worden herkend in de kritiek die meer specifiek is geleverd op de al genoemde in 2013 ingevoerde ZSM-werkwijze en de praktijk van de strafbeschikking. Bij de opzet en implementatie van de ZSM-werkwijze zouden politie en Openbaar Ministerie vooralsnog meer oog hebben gehad voor de oplossing van praktische vraagstukken die samenhangen met de beoogde versnelling van de afdoening van grote hoeveelheden eenvoudige strafzaken ${ }^{18}$, met als gevolg dat de aandacht voor strafvorderlijke waarborgen onderbedeeld is gebleven. Met die waarborgen wordt gedoeld op strafvorderlijke voorschriften met betrekking tot de vorming van processtukken en de uitoefening van verdedigingsrechten, in het bijzonder het recht op rechtsbijstand. ${ }^{19}$ Verder is gesteld dat de ZSM-werkwijze zou moeten worden gekarakteriseerd als een bestuurlijke aanpak van criminaliteit, die meer weg zou hebben van criminaliteitsbestrijding dan van rechtshandhaving. Ook zou deze werkwijze zich minder goed verdragen met de magistratelijke rol van de officier van justitie. ${ }^{20}$

Deze laatste opmerkingen zouden ook gelden voor de wijze waarop gebruik wordt gemaakt van de bevoegdheid tot het buitengerechtelijk afdoen van strafbare feiten door oplegging van een strafbeschikking. Beperkte Kooijmans zich in 2011 nog tot het stellen van de vraag 'of het openbaar ministerie zijn leidende rol kan waarmaken bij de controle achteraf-op de uitgevaardigde strafbeschikking, , ${ }^{21}$ inmiddels kan op deze vraag een antwoord worden gegeven. In een rapport van de ProcureurGeneraal bij de Hoge Raad zijn op basis van kwalitatief onderzoek naar de oplegging van strafbeschikkingen diverse tekortkomingen gesignaleerd. Zo zou in een substantieel deel van het aantal in het onderzoek betrokken zaken waarin door het Openbaar Ministerie een strafbeschikking was

18 Zie voor deze pragmatische inslag bijv. Openbaar Ministerie, 'Landelijk programma ZSM. Versnelde afhandeling van strafzaken', december 2012; J. Schagen, J. Renes \& I. van Duijneveldt, 'De impact van ZSM op ketensamenwerking', TvP, jg. 75/nr. 5/13, p. 14-18; J.J.A Lucas, 'ZSM - een huis dat samen gebouwd wordt, staat steviger', Strafblad 2013, p. 282-288.

19 Zie onder meer: T. Spronken, 'Het strafrecht als vergiet en het ZSM-model als snelkookpan', NbSr 2012, p. 373-376; P.T.C. van Kampen, 'ZSM \& tegenspraak', Strafblad 2013, p. 289-296; P. van der Meij, 'De andere kant van de ZSM-medaille', NJB 2014/1225; D.V.A. Brouwer, 'ZSM en de verdediging', DD 2015/26.

20 E. Sikkema \& F. Kristen, 'Strafbeschikking en ZSM: verschuivingen binnen de strafrechtshandhaving', in: Relaties van gezag en verantwoordelijkheid: strafrechtelijke ontwikkelingen, Boom Lemma uitgevers: Den Haag 2012, p.179-205. 
opgelegd, het bewijs ontoereikend moeten worden bevonden en had het niet mogen komen tot oplegging van een strafbeschikking. Verder zou er bij het uitvaardigen van strafbeschikkingen (structureel) sprake zijn van diverse procedurele tekortkomingen. ${ }^{22}$ Het rapport zou volgens Spronken illustreren 'wat er kan gebeuren als strafoplegging buiten het stramien van de controlerende ogen van de advocaat en de rechter in een setting zonder georganiseerde tegenspraak gebeurt' ${ }^{23}$

Het Openbaar Ministerie lijkt zijn werk bij het afdoen van strafbare feiten, gemeten langs de lat van juridische kwaliteit, dus niet goed te doen, zo kan uit de verschillende commentaren worden geconcludeerd. Klachten over prestaties van het Openbaar Ministerie in de dagdagelijkse praktijk lijken de juistheid van deze conclusie te bevestigen. In veel strafzaken blijkt de administratie niet op orde, is het procesdossier niet tijdig beschikbaar en/of incompleet, is de tenlasteleggingen ongelukkig opgesteld, is de doorstroming vertraagd, vertoont de verwerking van de rechterlijke uitspraak gebreken of staat de juistheid van de vervolgingsbeslissing ter discussie. Illustratief voor dit laatste is de stevige stijging van het aantal klachten waarin direct belanghebbenden zich beklagen over een beslissing van de officier van justitie om een strafbaar feit niet te vervolgen. ${ }^{24}$ Mensen aanvaarden een besluit van het Openbaar Ministerie niet meer als vanzelfsprekend, zo stelt Verburg. Op basis van zijn ervaring met de beoordeling van art. 12 Sv-klachten is zijn inschatting dat in ongeveer $10 \%$ van de klachtzaken het hof tot een andere afweging komt dan de officier van justitie. In die zaken wordt de sepotbeslissing van de officier van justitie gecorrigeerd en wordt beslist dat alsnog een vervolging moet worden ingesteld. ${ }^{25}$ En de bevindingen van de 'Onderzoekscommissie strafrechtelijke beslissingen openbaar ministerie naar aanleiding van de zaak Bart van $U$.' aangaande de tenuitvoerlegging van strafrechtelijke beslissingen en de uitvoering van DNA-onderzoek na een strafrechtelijke veroordeling lijken niet te duiden op incidentele missers, maar op structurele tekortkomingen in de organisatie van het Openbaar Ministerie. ${ }^{26}$

Zie het rapport van de procureur-generaal bij de Hoge Raad der Nederlanden, Beschikt en gewogen, Den Haag 2014.

Aldus T. Spronken, 'De wasstraat', NJB 2015/246.

Openbaar Ministerie, Jaarbericht 2014, p. 87.

Zie Joep Verburg, 'Rechters zijn geen bijzonder slag mensen meer', interview in NRC 1 augustus 2015.

26 Rapport van de onderzoekscommissie strafrechtelijke beslissingen openbaar ministerie naar aanleiding van de zaak Bart van U., Steenwijk 2015. 


\section{Achtergrond}

De weergegeven kritiek ziet in de breedte op het functioneren van het Openbaar Ministerie en de wijze waarop uitvoering wordt gegeven aan strafvorderlijke taken. Voor de in de kritieken gesignaleerde tekortkomingen zie ik twee hoofdoorzaken. Het betreft op de eerste plaats de nauwe band tussen politiek en strafrechtspleging. De tweede factor betreft de in samenhang te beschouwen reorganisatie van het Openbaar Ministerie en de opgelegde bezuinigingstaakstelling. Ik zal een en ander toelichten.

\section{Ad 1. Politiek en strafrechtspleging}

In de literatuur over de verhouding tussen de minister die politiek verantwoordelijk is voor de justitieportefeuille en het Openbaar Ministerie is frequent betoogd, dat er sprake moet zijn van afstandelijkheid tussen minister en Openbaar Ministerie. ${ }^{27}$ Deze afstandelijkheid impliceert dat de minister aan het Openbaar Ministerie ruimte moet laten voor de vormgeving van strafrechtelijk beleid en zich niet moet mengen in de dagdagelijkse praktijk van de opsporing en vervolging in individuele gevallen. In de hedendaagse bestuurlijk-politieke werkelijkheid is er van die ministeriële distantie maar weinig te merken. Het feitelijk functioneren van het Openbaar Ministerie, ook in concrete zaken, ligt voortdurend onder het politieke vergrootglas en de minister van V\&J heeft de strafrechtspleging stevig in de greep. Tevens is er sprake van een vergaande verstrengeling van het bestuurlijke criminaliteitsbeleid en het strafrechtelijke beleid van het Openbaar Ministerie. Deze actuele stand van zaken moet worden gezien als het eindresultaat van ontwikkelingen die in de jaren ' 80 van de vorige eeuw zijn ingezet. Markerend is het in 1985 door de regering gepresenteerde beleidsplan 'Samenleving en criminaliteit'. ${ }^{28}$ Dit beleidsplan bevatte een uitgebreid actieprogramma ter verbetering van de bestrijding van de zogenaamde kleine criminaliteit. Sedertdien hebben achtereenvolgende kabinetten beleidsplannen gelanceerd met telkens pakketten aan maatregelen ter verbetering

27 Zie bijv. uitvoerig A.C. 't Hart, Openbaar Ministerie en rechtshandhaving, Arnhem: Gouda Quint 1994, p. 296-338; H. de Doelder, Het Openbaar Ministerie in positie, Arnhem: Gouda Quint 1988, p. 13-14, en 'De vereiste afstand tussen het OM en de politiek', in: De inhoud van het gezag, OM-publicatiereeks 1996, p. 115-125.

Zie TK 1984/85, 18 995, Beleidsplan Samenleving en criminaliteit. 
van de strafrechtelijke rechtshandhaving. In deze beleidsplannen waren uiteenlopende kwesties aangaande de strafrechtspleging voorwerp van regeringszorg en -bemoeienis, zoals de ophelderingspercentages, de bestrijding van lichte en zware criminaliteit, de jeugdcriminaliteit, de lange duur van strafprocedures, de capaciteit van de organen van de strafrechtspleging, de effectiviteit van de strafrechtelijke sancties, de beteugeling van recidive enz. Een bijzondere tendens in de verschillende beleidsplannen is dat de met het ingezette beleid te bereiken doelstellingen steeds meer werden geformuleerd in de vorm van kwantitatief meetbare prestatiecijfers. Met deze cijfers werden geobjectiveerde doelen gesteld op basis waarvan kon worden getoetst of de in het kader van de beleidsprogramma's getroffen maatregelen leidden tot verbeteringen van het functioneren van de strafrechtspleging. Over de stand van uitvoering van de beleidsprogramma's en de al dan niet behaalde resultaten werd periodiek door de minister in de vorm van voortgangsrapportages aan het Parlement verslag uitgebracht. ${ }^{29}$ De prestatiecijfers en de voortgangsrapportages waren instrumenten voor politieke controle en sturing van de strafrechtspleging.

Het huidige programma ter versterking van de prestaties van de strafrechtsketen (VPS) past in deze lijn. Diverse speerpunten van VPS kunnen worden beschouwd als een voortzetting van ontwikkelingen die met voorafgaande beleidsplannen in gang zijn gezet. Met name kan worden gewezen op de aandacht voor de sturing van de opsporing door het Openbaar Ministerie, de wijze van afdoening van strafbare feiten, de doorstroomcijfers en de zogenaamde ongewenste uitstroom van zaken. Tegen de achtergrond van het eerder genoemde rapport van de Algemene Rekenkamer over de tekortschietende prestaties van de strafrechtsketen gaat het programma VPS echter veel verder dan het doortrekken van lijnen. Het programma is in veel sterkere mate dan eerdere beleidsplannen gericht op een integrale hervorming en modernisering van de strafrechtspleging. Hierbij ligt zwaar de nadruk op enerzijds efficiëntie en snelheid van strafrechtelijke procedures en anderzijds de werking van de organen van de strafrechtspleging als een keten waarin de opvolgende werkzaamheden op elkaar moeten zijn afgestemd en op elkaar aansluiten. 'Verliezen' in de zin van het verdwijnen van zaken of het verspillen van capaciteit moeten worden geminimaliseerd. In relatie tot de in-, door- en uitvoer van strafzaken

29 Zie over de verschillende beleidsplannen ter verbetering van de strafrechtspleging nader: De Meijer \& Simmelink, a.w. (2014), p.134-169. 
in de strafrechtsketen zijn in het programma voor de opsporing, vervolging en tenuitvoerlegging prestatiecijfers en taken geformuleerd. De voortgang bij de realisatie van de prestatiecijfers en de uitvoering van taken door politie, Openbaar Ministerie en zittende magistratuur wordt scherp bewaakt. Door de verschillende schakels van de strafrechtsketen zijn afspraken gemaakt over de prestaties die de een van de ander mag verwachten, zodat de capaciteit optimaal kan worden benut en financiële taakstellingen kunnen worden gehaald. ${ }^{30}$

Om zicht te krijgen op het functioneren van de strafrechtsketen en de behaalde prestaties hebben gezags- en verantwoordingsstructuren binnen het Openbaar Ministerie een invulling gekregen, waarbij cycli van 'planning \& control', kwantitatieve taakstellingen, afdoeningsquota, prestatieafspraken, maandrapportages, protocollering en een voortdurende monitoring van prestaties centraal staan. Van de dagelijkse werkprocessen moeten veel werkzaamheden worden geregistreerd om zicht te geven op voorraad, doorstroming, termijn en wijze van afdoening, etc. Incidenten leiden er vaak toe dat de registratieverplichtingen van activiteiten en beslissingen worden uitgebreid. Op deze wijze is de organisatie voorzien van de nodige registratieverplichtingen en 'prestatiemetertjes' waarvan de realisatie ieder afzonderlijk een punt van zorg is voor de leidinggevenden in de organisatie. Deze stand van zaken geeft voer aan critici die menen dat het functioneren van het Openbaar Ministerie meer wordt beheerst door interne controle en kwantitatieve output dan door kwaliteit van de strafrechtsbedeling. ${ }^{31}$

Een aan het voorgaande parallelle ontwikkeling betreft de verstrengeling van het beleid van het Openbaar Ministerie met het centrale en decentrale criminaliteitsbeleid. Ook deze ontwikkeling kan worden herleid tot het al genoemde beleidsplan Samenleving en Criminaliteit. Dit beleidsplan van de regering stelde voor de politie en het Openbaar Ministerie prioriteiten ten aanzien van de bestrijding van de kleine en zware criminaliteit en

30 Jaarlijks worden tussen gerechtelijke instanties en parketten 'convenanten' afgesloten, met daarin onder meer afspraken over aantallen aan te leveren zaken.

31 In dit verband bevat Recommendation (2000)19 van het Comité van Ministers van de Raad van Europa van 6 oktober 2000 'On The role of public prosecution in the criminal justice system ' onder nr. 36a een boeiende aanbeveling: 'With a view to promoting fair, consistent en efficient activity of public prosecutors, states should seek to: - give prime consideration to hierarchical methods of organisation, without however letting such organisational methods lead to ineffective or obstructive bureaucratic structures'. 
de inzet van opsporings- en vervolgingscapaciteit. Als de na Samenleving en Criminaliteit geopenbaarde plannen van de achtereenvolgende regeringen met betrekking tot het criminaliteitsbeleid in samenhang worden bezien met het strafrechtelijk beleid van het Openbaar Ministerie zoals daarvan blijkt uit de in de loop der jaren verschenen jaarverslagen en perspectiefnota's, dan is de rode draad in het verhaal dat het beleid van het Openbaar Ministerie wordt gedomineerd door het veiligheidsbeleid van de minister van V\&J. Het beleid van het Openbaar Ministerie borduurt voort op de prioriteiten die politiek zijn bepaald en vertaalt die prioriteiten naar de praktijk van de strafrechtspleging. In deze zin is het beleid van het Openbaar Ministerie niet meer bepalend, maar uitvoerend van aard geworden. Het effect van deze afhankelijke positie van het beleid van het Openbaar Ministerie is dat kritiek die in wezen betrekking heeft op het criminaliteitsbeleid van de regering wordt gericht op de uitvoerder van dat beleid. Commentaren op bijv. de eenzijdige focus op snelheid en efficiëncy in de ZSM-werkwijze en bij de buitengerechtelijke afdoening van strafbare feiten vind ik in dit opzicht illustratief.

Een belangrijkepijlervan het beleids planSamenlevingenCriminaliteitwas de gedachte dat kleine criminaliteit vooral moest worden tegengegaan door het treffen van preventieve matregelen door burgers, private instellingen en bestuur. Repressie stond op het tweede plan, waarbij uitgangspunt was: 'De organen van strafrechtspleging moeten op het gebied van de kleine criminaliteit ... hun middelen vooral inzetten als sluitstuk van een preventiebeleid van burger en bestuur'. Dit impliceerde dat de bestrijding van kleine criminaliteit vroeg om coördinatie van preventieve en repressieve inspanningen. Overleg en afstemming van het bestuurlijke en het strafrechtelijke optreden was noodzakelijk; een 'geïntegreerde bestuurlijke-justitiële aanpak' was aangewezen. ${ }^{32}$ Sedertdien is het inzicht gegroeid dat het Openbaar Ministerie bij de rechtshandhaving moet streven naar samenwerking met andere publieke en private instanties. De gevoelde noodzaak tot samenwerking berust op de gedachte dat strafrechtelijke interventies aan betekenis winnen als deze deel uitmaken van een criminaliteitsbeleid dat het resultaat is van samenwerking van publieke en private organisaties in een veiligheidsnetwerk. Deze benadering wordt gekwalificeerd als een 'geïntegreerde', 'integrale' of 'programmatische' aanpak. De essentie hiervan is dat een effectieve bestrijding van criminaliteit meer vraagt dan 
alleen repressief optreden door politie en Openbaar Ministerie, namelijk samenwerking met andere organisaties die zelf ook gebruik kunnen maken van interventie- en sanctiemogelijkheden: 'Vertrekpunt ... is de maatschappelijke problematiek die gesignaleerd wordt om van daaruit een gezamenlijke, programmatische aanpak te ontwikkelen en over te gaan tot actie'. In deze benadering neemt het Openbaar Ministerie tegenwoordig deel aan een groot aantal samenwerkingsverbanden met instanties die een rol kunnen spelen bij de rechtshandhaving, zoals 'het (openbaar) bestuur, scholen, zorginstellingen, woningcorporaties, Belastingdienst, bestuurlijke handhavingsdiensten, civiele jeugdzorg, slachtofferzorg, ondernemers, OV-bedrijven, kennisinstituten, et cetera'.33 De inzet is dat door het Openbaar Ministerie 'met partners wordt overlegd welke mix van strafrechtelijke, bestuurlijke, fiscale en andere interventies het effectiefst is om de achterliggende problematiek effectief terug te dringen'. 34 Hieruit volgt dat het strafrechtelijk beleid wordt ingebed in een breder gedragen handhavingsbeleid 35 en daarvan afhankelijk is. Die afhankelijkheid ziet niet alleen op de effectiviteit van het strafrechtelijk optreden, maar ook op de verantwoordelijkheid voor de rechtshandhaving. ${ }^{36} \mathrm{Dit}$ is ook tot uitdrukking gebracht in Perspectief op 2015, als wordt gesteld: 'Samenwerken in een netwerk veronderstelt wederkerige relaties. Het OM staat open voor beïnvloeding door de prioriteiten en strategieën die het openbaar bestuur kiest. Het Openbaar Ministerie heeft oog voor de belangen van andere partners en is bereid het strafrecht als onderdeel van een gezamenlijke handhavingsstrategie in te zetten.' De gedeelde verantwoordelijkheid maakt het Openbaar Ministerie kwetsbaar. Tekortkomingen in de uitvoering van het gezamenlijk gedragen beleid kunnen immers in verband met de spilpositie in het strafproces aan het Openbaar Ministerie worden toegeschreven.

33 Openbaar Ministerie, Perspectief op 2015, p. 7 .

34 Openbaar Ministerie, Jaarbericht 2014, p. 13.

35 Vergelijk Jaarbericht 2014, p. 7, waar wordt aangegeven: ' De ambities voor de komende jaren zijn neergelegd in de gemeenschappelijke veiligheidsagenda van de minister van Veiligheid en Justitie, regioburgemeesters, College en politie.

36 Openbaar Ministerie, Perspectief op 2015, p. 7 . 


\section{Ad 2. Bezuinigingen en reorganisatie}

De tweede factor ter verklaring van de kritiek op het hedendaagse functioneren van het Openbaar Ministerie betreft de krimp in het budget van de organisatie en lopende reorganisatieprocessen. In het kader van de overheidsbezuinigingen heeft het Openbaar Ministerie, in stappen en uitgesmeerd over een aantal jaren,37 te maken met een reductie van het beschikbare budget met ruim een kwart. Deze forse budgettaire korting maakte bezinning op de inrichting van de organisatie noodzakelijk. In die bezinning moesten pijnlijke keuzes worden gemaakt over huisvesting en invulling van arbeidsplaatsen. Dit leidde ertoe dat huisvesting werd ingekrompen en geconcentreerd. Ingrijpender is dat arbeidsplaatsen werden geschrapt, met name bij de administratieve en secretariële ondersteuning. Ondanks de krimp van het budget en van het personeelsbestand zijn de kwantitatieve taakstellingen van de organisatie gelijk gebleven. Dit betekent dat een gelijkblijvende werklast moet worden gedragen door een kleiner personeelsbestand, met als gevolg dat de individuele werklast verzwaart. Tegelijkertijd worden in de verschillende beleidsplannen, ook van de eigen organisatie, hoge eisen gesteld aan de inhoudelijke kwaliteit van het werk van het Openbaar Ministerie. ${ }^{38}$ Verzwaring van werklast met behoud, en liefst verhoging van kwaliteit van werk zijn evenwel lastig verenigbare uitgangspunten, met spanningen in de organisatie tot gevolg. Blijkens de Jaarberichten over 2013 en 2014 hebben deze spanningen vooralsnog geen gevolgen gehad voor de strafrechtelijke productie. Gemeld werd dat de beoogde resultaten in 2013 en 2014 werden gerealiseerd. Wel werd opgemerkt dat de grenzen van het presterend vermogen van de organisatie zijn bereikt. Het Jaarbericht over 2014 meldde hierover: de organisatie 'functioneert in alle opzichten aan de randen van zijn kunnen'.39 En dat is goed voelbaar op de werkvloer, onder meer blijkende uit het gegeven dat primaire werkprocessen regelmatig slechts met kunst en vliegwerk en kortetermijnoplossingen overeind blijven. Dat gaat in de richting van overbelasting van de organisatie.

Om te voorkomen dat de personeelsreductie op den duur het presterend vermogen van de organisatie aantast, zijn voor de langere termijn randvoorwaarden geformuleerd, waaraan moet zijn voldaan om bij een gekrompen budget dat presterend vermogen te behouden. Deze 
randvoorwaarden bestaan uit digitalisering van de strafrechtsketen, een verbetering van de kwaliteit van werkprocessen en een efficiëntere bedrijfsvoering. ${ }^{40}$ Voor de uitvoering van werkzaamheden ter realisatie van deze vernieuwingen zijn flinke investeringen noodzakelijk. Het is de vraag of in het huidige budget hiervoor de nodige financiële middelen kunnen worden vrijgemaakt. Recent heeft de Galan Groep een rapport uitgebracht ${ }^{41}$, waarin verslag wordt gedaan van een onderzoek naar de haalbaarheid van de budgettaire taakstellingen voor het Openbaar Ministerie in de komende jaren en de mogelijkheid om in die periode de noodzakelijk geachte vernieuwingen door te voeren. De conclusies van dit rapport vind ik erg verontrustend. Gesteld wordt dat het Openbaar Ministerie in de huidige context en binnen het gestelde tijdpad niet in staat is om tegelijkertijd de opgelegde bezuiningen en de nodige vernieuwingen te realiseren. Als die vernieuwingen uitblijven, loopt het Openbaar Ministerie aan tegen de grenzen aan van verantwoord bezuinigen. De Galan Groep voorziet dan ook 'stevige risico's voor het primair proces, de borging van kwaliteit en het leveren van public value (met op langere termijn mogelijk negatieve gevolgen voor het $\mathrm{OM}$ als gezaghebbend onderdeel van de strafrechtketen en de externe legitimiteit). ${ }^{\prime 2}$ Ik kan hierin geen woord Spaans ontdekken. De waarschuwende woorden van de Galan Groep brengen de noodzaak tot het maken van keuzes en het stellen van prioriteiten ten aanzien van de uitvoering van werkzaamheden erg dichtbij.

De bezuinigingen hebben een aanjagend effect gehad op het doorvoeren van veranderingen in de organisatie van het Openbaar Ministerie. De ontwikkelingsrichting van het Openbaar Ministerie is neergelegd in het 'Programma OM 2020'.43 De reorganisatieplannen gaan uit van een stevige personeelsreductie en een opbouw van het Openbaar Ministerie in zogenaamde 'geïntegreerde werkomgevingen': een productieomgeving voor een gestandaardiseerde behandeling van eenvoudige zaken, een interventieomgeving overeenkomstig de ZSMwerkwijze, een onderzoeksomgeving voor met name de zogenaamde Ministerie', Baarn 2015. Het onderzoek door de Galan Groep is uitgevoerd op verzoek van het College van Procureurs-Generaal.

42 Rapport Galan Groep, p. 32.

43

Zie Openbaar Ministerie, Jaarbericht 2013, p. 58-59; Jaarbericht 2014, p. 78-79.

Galan Groep, Actualisatie validatie-onderzoek haalbaarheid budgettair kader Openbaar

Zie over 'OM 2020' nader: De Meijer \& Simmelink, a.w. (2014), p. 206-212. 
'high impact crime', een onderzoeksomgeving voor ondermijnende criminaliteit en het hoger beroep. Deze werkomgevingen worden weerspiegeld in de verschillende onderdelen van de organisatie: het parket CVOM, het Arrondissementsparket, het Functioneel Parket, het Landelijk Parket en het Ressortsparket. De veranderingsprocessen in relatie tot de bezuinigingen en de lopende reoganisatie brengen mee dat het Openbaar Ministerie tot 2020 'in transitie' is.44 De verzuchting van Frielink naar aanleiding van eerdere reorganisatieprocessen - 'Zo langzamerhand wordt het tijd voor rust in de tent' - is een wens waarvan de realisatie dus nog wel even op zich laat wachten. ${ }^{45}$

Bezuinigingen, veranderingsprocessen en reorganisaties hebben gevolgen voor het functioneren van organisaties. Tijd, energie en capaciteit gaan verloren door onzekerheden en onduidelijkheden aangaande de ontwikkelingsrichtingen en het opkomen van fricties in de werkprocessen. Voor het Openbaar Ministerie is dat niet anders. Een verder effect van de ingrijpende veranderingen is dat het Openbaar Ministerie als organisatie last heeft van, zoals Buruma dat heeft genoemd, 'institutionele preoccupaties'.$^{46}$ In moeilijke tijden is de organisatie teveel gericht op het eigen presteren overeenkomstig interne regels en procedures en kwantitatieve taakstellingen, met als gevolg dat de aandacht voor rechtsstatelijke vraagstukken in de verdrukking raakt. Dat geeft vanzelf aanleiding tot lastige vragen over de rechtsstatelijke kwaliteit van het werk van het Openbaar Ministerie.

\section{Positiebepaling}

De problemen zijn belicht. In het actuele functioneren van het Openbaar Ministerie staan de taak van de organisatie om te waken over de rechtsstatelijkheid van de opsporing en vervolging en een magistratelijke taakopvatting van de officier van justitie inderdaad onder druk. In dit verband spreekt Schalken over 'een tijdperk, waarin rechtsstatelijke normen en waarden onder druk staan als gevolg van bezuinigingen, reorganisaties, productiedruk, nadruk op procesmanagement et cetera' ${ }^{4} 77$ Debet daaraan zijn de sterke greep van de politiek op het Openbaar

\footnotetext{
44 TK 2013/14, 29 279, nr. 177, p. 9-10.

45 Frielink, a.w. (2010), p. 10.

46 Y. Buruma, 'Rapport morale', NJB 2014, p. 1340-1342.

47 Noot onder HR 7 juli 2015, NJ 2015, 363.
} 
Ministerie, de verwevenheid van het bestuurlijke en strafrechtelijke handhavingsbeleid en de bezuinigingen en reorganisaties. In deze dynamiek kost het de organisatie veel moeite om het spreekwoordelijke hoofd boven water te houden. Op onderdelen is het voorgaande veranderlijk. Aan reorganisaties komt een keer een eind. Dat is althans te hopen. Ik zie het echter niet gebeuren dat de greep van de minister op de strafrechtspleging verslapt of dat, ondanks de signalen van de Galan Groep, de bezuinigingen worden afgeblazen of getemperd. De politieke dominantie en de bezuinigingstaakstelling zijn echter wel de belangrijkste oorzaken voor de druk op het functioneren van het Openbaar Ministerie. Dit moet echter geen aanleiding geven om dan maar te accepteren dat, zoals Franken heeft gesuggereerd, het Openbaar Ministerie niets anders is dan een buitendienst van het ministerie van $V \& J$ en dat officieren van justitie uitvoerende ambtenaren en geen magistraten zijn..$^{8}$ Acceptatie van deze gedachten zou namelijk forse consequenties hebben voor de inrichting van het strafprocesrecht en slaat bovendien een van de pijlers onder het bestaansrecht van het Openbaar Ministerie weg. Dit hangt samen met de tweeledige verankering van het Openbaar Ministerie in het staatsbestel en het karakter van het Nederlandse strafprocesrecht.

Het Openbaar Ministerie in het staatsbestel: bestuur en magistraat

De positie van het Openbaar Ministerie in het staatsbestel is bijzonder.49 Enerzijds staat het Openbaar Ministerie onder het gezag van de minister van $V \& J^{50}$ en is de organisatie een deel van het uitvoerende domein. Staatsrechtelijk heeft het Openbaar Ministerie de status van gedeconcentreerd bestuursorgaan..$^{5}$ Anderzijds is het Openbaar Ministerie een onderdeel van de rechterlijke macht en wordt de officier van justitie aangemerkt als 'rechterlijk ambtenaar' in de zin van de Wet RO. Over deze tweeledige positie van het Openbaar Ministerie en de

48 A.A. Franken, 'De kosten van de strafvordering en de kosten van detentie', DD 2015/42, p. 433 , voetnoot 25 .

49 Hierover nader D. van Daele, Openbaar Ministerie en strafrechtelijk beleid, AntwerpenGroningen: Intersentia 2002, p. 102-115

50 Zie art. 127 RO.

51 Vgl. Van de Bunt \& Beckers, a.w. (2013), p. 295-296; L.J.J. Rogier, 'Het OM als bestuursorgaan', in: E. Bleichrodt e.a. (red.), Onbegrensd strafrecht, Nijmegen:WLP 2013, p. 349-359; W. Witteveen, a.w. (1998), p. 450. 
consequenties daarvan is in het verleden veel gedebatteerd. Het debat bestond in de kern uit een stellingname vanuit een staatsrechtelijk of een rechtsstatelijk perspectief. Van de Bunt en Beckers geven aan dat het debat met een breed geaccepteerd uitgangspunt tot rust is gekomen. Zij stellen: 'De heersende gedachte is dat het Openbaar Ministerie op beleidsniveau tot de uitvoerende macht behoort, maar op concreet zaaksniveau in zijn hoedanigheid als magistraat deel uitmaakt van de rechterlijke macht'. ${ }^{2}$ I $\mathrm{k}$ betwijfel of de woorden van Van de Bunt en Beckers inderdaad een heersende gedachte weergeven. In ieder geval meen ik dat het door hen aangebrachte onderscheid aan de hand van een beleidsniveau en een zaaksniveau niet houdbaar is. Voor de positionering van het Openbaar Ministerie is het onderscheid tussen die twee niveau's te diffuus. Belangrijker is dat het uitvoerende en het magistratelijke in het werk van het Openbaar Ministerie verweven zijn. Strafrechtelijk beleid en het optreden in individuele zaken zijn tegelijkertijd bestuur en magistratelijk. 53 Richtlijnen voor strafvordering en vervolgingsbeslissingen in individuele zaken zijn enerzijds bestuurlijk van aard, maar zijn anderzijds ook georiënteerd op een magistratelijk handelen. ${ }^{54} \mathrm{Het}$ is aan het Openbaar Ministerie om in zijn taakuitoefening op alle niveau's beide elementen te verenigen. ${ }^{55}$ Hierbij ligt de uitdaging met name in het magistratelijke element. In moeilijke tijden, zoals reorganisaties, bezuinigingen, een politieke roep om meer veiligheid en efficiëntie, gaat het strafrechtelijk bestuur wel door. Als gevolg van druk op de organisatie en de werklast gaat de aandacht vanzelf meer richting het behoud van kwantitatieve prestaties en minder naar kwalitatieve elementen in de strafrechtspleging.

De positionering van het Openbaar Ministerie als onderdeel van de rechterlijke macht betekent dat het Openbaar Ministerie meer is dan een buitendienst van het Ministerie van $V \& J$ en dat de officier van justitie niet slechts een uitvoerende ambtenaar is. Dat meerdere moet

52 Zie Van de Bunt en Beckers, a.w. (2013), p. 292.

53 Vgl. Van Daele, a.w. (2002), p. 115, die het Openbaar Ministerie een organisatie sui generis noemt.

54 Aanwijzingen en richtlijnen staan immers in het teken van bevordering van gelijkheid, voorspelbaarheid en het voorkomen van willekeur.

55 Zie A.C. 't Hart, a.w. (1994), p. 312: 'De beleidsvoering en de zelfstandige positie ten opzichte van de rechter laten onverlet dat het OM zich, vanuit de oriëntatie op het recht, bij de hantering van zijn bevoegdheden 'rechterlijk' opstelt. Dat houdt voor de leden van het OM een opdracht in, waaraan zij zelf in hun dagelijks handelen inhoud dienen te geven. Ook het beleid is erop gericht de rechtsstaat feitelijk gestalte te geven '. 
een waarborg zijn voor de rechtsstatelijkheid van het strafproces en de realisatie van de doelstellingen van het strafprocesrecht. Dit klinkt behoorlijk principieel. De vraag is dan of duidelijk kan worden gemaakt wat deze principieel aangezette waarborg inhoudt. Wesselink heeft de magistratelijkheid van het Openbaar Ministerie en van de officier van justitie omschreven als een '(juridisch) professioneel handelen, vanuit de in de wet vastgelegde taak, binnen de kaders van de wettelijke regelingen, rechtmatig en opportuun, waarbij het vooral gaat om waarheidsvinding ${ }^{\prime} .^{6}$ Naar mijn oordeel wordt met deze omschrijving weinig toegevoegd aan de professionele attitude die mag worden gevergd van iedere ambtenaar die met handhavingstaken is belast. Zo mogen de door Wesselink genoemde eisen niet alleen worden gevergd van het Openbaar Ministerie en zijn leden, maar ook van de politieambtenaar die een verkeersboete uitdeelt, de belastingambtenaar die een fiscale boete oplegt of de Voedsel- en Warenautoriteit die een boete oplegt wegens handelen in strijd met bijv. de Drank- en horecawet. Voor de omlijning van de magistratelijkheid van het Openbaar Ministerie moet dus een verdiepingsslag worden gemaakt. Mijn eerste aanknopingspunt hiervoor is het 'kernprofiel' van de officier van justitie, zoals omschreven in het Onderzoeksproject Strafvordering 2001. Een kernprofiel bestaat in dit onderzoeksproject uit 'een verschijningsvorm van systeembepalende gezichtspunten': 'ijkpunten die de harde structuur moeten bieden aan een in zijn aard veranderbare positiefrechtelijke regeling'.57 Op de tweede plaats geven internationale documenten inspiratie voor de verdiepingsslag. In het bijzonder doel ik op een Aanbeveling van de Raad van Europa over 'the role of public prosecution in the criminal justice system' 58 , de 'European Guidelines on ethics and conduct for public prosecutors' ('the Budapest guidelines')59 en 'the Rome charter on European norms and principles concerning prosecutors'. ${ }^{60}$ Deze documenten bevatten regels voor professioneel handelen in het

56 J.H. Wesselink, 'De magistratelijkheid van het Openbaar Ministerie', in RM Themis 2011, $\mathrm{nr}$. 4, p. 179-184.

57 M.S. Groenhuijsen\&G. Knigge, a.w. (1999), p. 32 en a.w. (2004), p. 77. Zie over het kernprofiel van de officier van justitie ook T. Kooijmans, Dat is mijn zaak!, oratie, Tilburg 2011, p. 39-45.

$58 \operatorname{Rec}(2000) 19$ van 6 oktober 2000.

59 European Guidelines on ethics and conduct for public prosecutors, adopted by the Conference of Prosecutors General of Europe, Straatsburg, 31 mei 2005.

60 Consultative council of European prosecutors, Opinion no. 9 (2014) on European norms and principles concerning prosecutors, Straatsburg 17 december 2014. 
algemeen en in het kader van strafrechtelijke procedures. Ten derde kan worden aangeknoopt bij doelstellingen en grondtrekken van het strafprocesrecht. In samenhang kan de magistratelijkheid van het Openbaar Ministerie en van de officier van justitie worden bezien vanuit de volgende invalshoeken:

\section{Onpartijdigheid van functie-uitoefening}

De officier van justitie is in het strafproces geen procespartij. Hij heeft geen eigen belangen bij de uitkomst van de zaak en mag zich niet laten leiden door de belangen van bekenden, familieleden, zakelijke relaties of door druk vanuit de media of de politiek. Criminaliteitsbestrijding als doel of belang moet worden afgewogen tegen de belangen van de verdachte, het slachtoffer, getuigen en verdere betrokkenen bij het strafgeding. Persoonlijke gedrevenheid mag er niet toe leiden, dat een standpunt wordt vertolkt of beslissingen worden genomen die niet stroken met de feiten of het toepasselijke recht. ${ }^{61}$ Hieruit volgt dat de officier van justitie zich onpartijdig en integer dient op te stellen. Hij moet alle bij de zaak betrokken belangen op objectieve wijze afwegen; hij mag niet eenzijdig het vervolgingsbelang of het belang van het slachtoffer laten doorslaan. De verlangde onpartijdigheid impliceert dat de vervolgingsbeslissing in beginsel gevrijwaard dient te zijn van beïnvloeding door politieke organen. De inhoud van de vervolgingsbeslissing kan weliswaar worden gekleurd door het geldende vervolgingsbeleid, maar de officier van justitie moet waken voor politieke beïnvloeding van de concrete vervolgingsbeslissing. ${ }^{62}$ In deze zin moet de officier van justitie onafhankelijk zijn taak kunnen uitoefenen. Als er sprake is van politieke beïnvloeding, moet deze transparant worden gemaakt. Als de vervolgingsbeslissing het resultaat is van afwegingen van politieke organen waaraan de officier van justitie op grond van de hiërarchische verhoudingen gebonden is, zal hij ter zitting van deze achtergrond moeten doen blijken.

61 Zie Gedragscode OM 2012, p. 13.

62 Zie in dit verband ook de Standards of Professional Responsibilities and Statement of the Essential Duties and Rights of Prosecutors (The International Association of Prosecutors: The IAP Standards 1999, overgenomen door de VN in 2008 (Resolution 2008/5 van de UN Commission on Crime Prevention and Criminal Justice), waarin is aangegeven dat 'The use of prosecutorial discretion, when permitted in a particular jurisdiction, should be exercised independently and be free from political interference'. De 'European Guidelines for Ethics and Conduct for public prosecutors' (Consultative of European Prosecutors (CCPE), Raad van Europa 2005) formuleren soortgelijke uitgangspunten. 


\section{Waarheidsbegrip}

De officier van justitie moet streven naar een correcte toepassing van het recht. Voor het feitenonderzoek impliceert deze gehoudenheid een zoektocht naar de 'materiële waarheid'. Met het nemen van beslissingen op basis van een materieel waarheidsbegrip kan worden voorkomen dat onschuldigen ten onrechte worden bestraft en onterecht als verdachte worden geconfronteerd met de toepassing van (ingrijpende) strafvorderlijke dwangmiddelen en onderzoeksbevoegdheden. ${ }^{63}$ Het materiële waarheidsbegrip impliceert dat in het onderzoek onpartijdig alle belastende en ontlastende gegevens moeten worden betrokken en dat van een en ander ook moet blijken uit het procesdossier. Op deze wijze wordt recht gedaan aan het beginsel van equality of arms.

\section{Eerlijkheid en behoorlijkheid van het strafproces}

De officier van justitie heeft te waken over de eerlijkheid van het proces, de respectering van het onschuldvermoeden, de inachtneming van waarborgen die aan de verdachte zijn toegekend en een inzet van strafrechtelijke middelen die voldoet aan 'kwaliteitseisen van rechtsstatelijkheid'. ${ }^{64}$ Deze opdracht brengt mee dat de officier van justitie in het opsporingsonderzoek een kritische distantie dient te betrachten ten aanzien van het werk van de politie en de uitkomsten van het opsporingsonderzoek. Voorts moet de officier toezicht houden op de rechtmatigheid van de toepassing van dwangmiddelen en opsporingsbevoegdheden. Als blijkt van ernstig onrechtmatig handelen, moeten daaraan consequenties worden verbonden in de zaak. Tevens moeten maatregelen worden getroffen om toekomstige gelijksoortige schendingen te voorkomen. Verder moet de officier instaan voor de juistheid en juiste maat van de door hem genomen beslissingen.

\section{Organisatie}

De drie voorgaande elementen lijken te duiden op de taakopvatting van de officier van justitie als individueel functionaris. Ik meen echter dat deze elementen ook op een hoger plan kunnen worden getrokken en betekenis hebben voor de organisatie als zodanig. In dit verband zou ik willen spreken over zorg voor de organisatie dat de rechtshandhaving in alle opzichten evenwichtig kan worden genoemd. Deze zorg ziet niet

63 Vgl. G. Knigge, 'De strafvordering in het geding', in: Herbezinning op (de grondslagen van) het Wetboek van Strafvordering, Handelingen NJV 1994-I, p. 55-60.

64 A.C. 't Hart, a.w. (1994), p. 320. 
alleen op de opsporing en vervolging in individuele zaken, maar juist op het geheel, het brede scala van strafbare feiten, van licht en eenvoudig tot ernstig en complex. Bij een evenwichtige rechtshandhaving bestaat evenredigheid tussen doelen en middelen, een doelmatige besteding van middelen en menskracht en de realisatie van rechtsstatelijke beginselen (zoals het gelijkheidsbeginsel, het vertrouwensbeginsel en de rule of law). Ter bevordering van deze evenwichtigheid staan de organisatie verschillende instrumenten ter beschikking, zoals beleidsregels en mechanismen van toezicht.

De gegeven invalshoeken maken voldoende duidelijk wat de rechtsstatelijke betekenis is van de magistratelijkheid van het Openbaar Ministerie en de officier van justitie. Dat deze magistratelijkheid moet worden beschouwd als een belangrijke waarborg in relatie tot de centrale rol van de officier van justitie in het strafproces, houdt verband met het karakter van het Nederlandse strafprocesrecht.

\section{Karakter van het strafprocesrecht}

Thans wordt uitgebreid gesleuteld aan de strafvorderlijke wetgeving. Een grootschalig wetgevingsproject moet leiden tot de modernisering van het strafprocesrecht. De beoogde modernisering heeft betrekking op uiteenlopende kwesties: de regeling van de bevoegdheden en procespositie van de deelnemers aan het strafproces, vereenvoudiging van de regeling van de opsporingsbevoegdheden, vrijheidsbeperking en vrijheidsbeneming, stroomlijning van procedures, verkorting van doorlooptijden en digitalisering. De veranderingen moeten leiden tot 'een wetboek dat systematisch van opzet is, het toepasselijke recht weerspiegelt, een logische indeling kent en inzichtelijk is voor de burger'. ${ }^{65}$ De modernisering van het wetboek leidt echter niet tot een fundamentele herziening van het strafprocesrecht; 'belangrijke uitgangspunten' van het huidige wetboek blijven behouden. 'Zo blijft hoofddoel van het strafproces dat sprake dient te zijn van een "goed ingericht strafproces» dat zoveel mogelijk bevordert dat de strafwet wordt toegepast op de "werkelijk schuldige» en dat naar vermogen de veroordeling van de niet-schuldige verhindert.' 66 Voorts blijt 'gelden dat opsporingsambtenaren onder het gezag van het OM de opsporing

65 TK 2015/16, 29 279, nr 278, brief van de minister van V\&J bij de Contourennota, p. 4.

66 TK 2015/16, nr. 29 279, nr 278, brief van de minister van V\&J bij de Contourennota, p. 16 : 'Beklemtoond moet worden dat de beginselen en belangrijke uitgangspunten die aan het huidige wetboek ten grondslag liggen behouden blijven. 
verrichten overeenkomstig de normering die het wetboek daaraan stelt. ... Van belang is dat het OM tegenover de rechter aanspreekbaar is op de wijze waarop het opsporingsonderzoek is uitgevoerd.' Verder behoudt het Openbaar Ministerie het vervolgingsmonopolie en de bevoegdheid om wenselijkheid en omvang van de vervolging te bepalen (het opportuniteitsbeginsel). ${ }^{67}$ Tenslotte moet de modernisering ertoe leiden dat in de toekomst het voorbereidend onderzoek aan betekenis wint. Het vooronderzoek 'bepaalt in belangrijke mate het verdere verloop van het proces en de kwaliteit van de procedure als geheel' en bevordert 'de deugdelijkheid en kwaliteit van de over de zaak te nemen beslissingen'. Om deze reden wordt de betrokkenheid van de rechter-commissaris en van de verdediging bij het voorbereidend onderzoek versterkt.

Het behoud van de genoemde uitgangspunten en de versteviging van het belang van het vooronderzoek impliceren dat het Nederlandse strafprocesrecht ook in de toekomst in zijn grondtrekken inquisitoir van aard is. Weliswaar staat het hedendaagse strafprocesrecht in de sleutel van de contradictoiriteit en versteviging van de positie van de verdediging, dit kan echter niet verbloemen dat het strafprocesrecht berust op inquisitoire fundamenten. ${ }^{68}$ De verhoudingen tussen Openbaar Ministerie, verdediging en rechter en de taken van de verschillende procesdeelnemers kunnen alleen maar goed worden begrepen in het licht van die fundamenten. De inquisitoire grondtrekken zou ik als volgt willen duiden. Het strafproces is gericht op opheldering van de materiële waarheid door middel van een van overheidswege in te stellen onafhankelijk en onpartijdig onderzoek. Onderzoekende ambtenaren hebben tot taak alle belastende en ontlastende gegevens te inventariseren. Voor de uitvoering van het onderzoek zijn aan de overheid machtsmiddelen en onderzoeksbevoegdheden toegekend. Het vooronderzoek is de belangrijkste fase in het strafproces, omdat daar het onderzoek naar de waarheid feitelijk plaatsvindt. Het procesrecht moet waarborgen bieden ter voorkoming van willekeur en misbruik van overheidsmacht. Naast wettelijke beperkingen op machtsmiddelen en onderzoeksbevoegdheden zijn mogelijkheden tot controle een belangrijke waarborg voor de rechtmatigheid en volledigheid van het onderzoek. In het strafprocesrecht moeten garanties worden ingebouwd

67 TK 2015/16, nr. 29 279, nr 278, brief van de minister van V\&J bij de Contourennota, p. 5-6.

68 Anders: P. de Hert en T. Decaigny, 'Evolueren het Nederlandse en het Belgische strafproces naar adversaire systemen', in: Strafblad 2013, p. 54-66. 
voor de volledigheid van het voor- en eindonderzoek, de betrouwbaarheid van het verzamelde bewijsmateriaal en de juistheid van het eindoordeel van de rechter. ${ }^{69}$

\section{Samenhang}

De inquisitoire grondtrekken van het strafprocesrecht en de magistratelijkheid van het Openbaar Ministerie en de officier van justitie vertonen samenhang. Een magistratelijke taakuitoefening is een belangrijke waarborg in relatie tot de realisatie van doelstellingen van strafprocesrecht,zoals waarheidsvinding, controle over de rechtmatigheid van opsporing en vervolging, de samenstelling van het procesdossier en een evenredige afweging van belangen bij de afdoening van de zaak. Als het Openbaar Ministerie deze waarborg niet kan bieden, hoort dat consequenties te hebben voor de inrichting van het strafprocesrecht. In plaats van een magistratelijke taakopvatting zal de wetgever alternatieve waarborgen moeten creëren om te verzekeren dat het strafvorderlijke onderzoek in alle opzichten volledig en rechtmatig verloopt. Hierbij zullen zeggenschap, verantwoordelijkheden en bevoegdheden over de opsporing en vervolging moeten worden herverdeeld over politie, Openbaar Ministerie, verdediging, rechter en wellicht een nieuw te creëren autoriteit. Dit zou betekenen dat het strafprocesrecht toch fundamenteel op de schop zou moeten. Zover moet het wat mij betreft niet komen. Ik meen dat er onvoldoende aanleiding bestaat voor een dergelijke ingrijpende hervormingsoperatie. Ook bij de toekomstige inrichting van het strafprocesrecht moet worden uitgegaan van een Openbaar Ministerie dat deel uitmaakt van de rechterlijke macht en dat daadwerkelijk inhoud wil geven aan de hierin besloten liggende waarborgen voor de rechtmatigheid en integriteit van het strafproces. Hierin ligt naar mijn overtuiging ook het bestaansrecht van de organisatie. Zonder een magistratelijke taakopvatting zou het Openbaar Ministerie een bestuursorgaan zijn als geen ander en bestaat er geen enkel bezwaar om taken die nu zijn gereserveerd voor het Openbaar Ministerie (ook) toe te delen aan andere handhavingsautoriteiten. In deze voor het Openbaar Ministerie woelige tijden zie ik het dan ook als de meest wezenlijke opdracht voor de organisatie om pal te staan voor wat ik zie als een kernwaarde voor het Openbaar Ministerie.

69 Hierover uitvoerig A. Ringnalda in zijn boeiende proefschrift Convergence and traditions of criminal procedure. Fair truth finding and the changing role of the prosecutor in the Netherlands and England \& Wales, UU 2015, hoofdstukken 6, 7 en 8. 


\section{Moderniseringen}

Voor een fundamentele wijziging van de positie en taak van het Openbaar Ministerie in het toekomstige strafprocesrecht bestaat naar mijn oordeel dus geen aanleiding. Ik kan mij volledig vinden in de keuze van de wetgever voor behoud van de spilpositie van het Openbaar Ministerie in het strafproces. De modernisering van het Wetboek van Strafvordering biedt kansen om de positie van het Openbaar Ministerie te verstevigen. De Contourennota geeft hiervoor al de nodige voorzetten. Op deze plaats wil ik enkele thema's bespreken die in die Contourennota wat onderbelicht zijn gebleven of nog open zijn gelaten. Wat mij betreft verdienen deze onderwerpen bij de voortgaande modernisering van het strafprocesrecht aandacht, omdat daarmee de rechtstatelijke kwaliteit van het strafprocesrecht kan worden verbeterd.

\section{Samenwerking en gegevensuitwisseling}

Het eerste onderwerp betreft de samenwerking tussen het Openbaar Ministerie en andere publieke en private organisaties in het kader van een 'geïntegreerde rechtshandhaving'. De basisgedachte in dit handhavingsmodel is dat de effectiviteit van strafrechtelijke interventies aan betekenis wint, wanneer het strafrechtelijke optreden wordt geflankeerd door een breder beleid van bestuurlijke autoriteiten, gezondheidszorg, reclassering, jeugdzorg etc. Ten behoeve van de coördinatie van de strafrechtelijke handhavingsinspanningen met het optreden van andere organisaties zijn in de praktijk vele overlegstructuren en samenwerkingsverbanden ontstaan. Veelal worden samenwerkingsverbanden geformaliseerd in convenanten, waarin het doel en de opzet van de samenwerking en de door iedere deelnemende instantie te leveren bijdrage worden beschreven. De zinvolheid van overleg en samenwerking staat of valt met het delen van informatie waarover de verschillende betrokken partijen beschikken. Een integrale aanpak van bijv. de georganiseerde hennepteelt is alleen mogelijk als Openbaar Ministerie, politie, gemeentes, UWV, fiscus, woningcorporaties en energiemaatschappijen bereid en in staat zijn relevante informatie te delen met de andere deelnemers aan het samenwerkingsverband, zodat op basis van alle beschikbare informatie beleid kan worden uitgestippeld. Het delen en gebruiken van informatie in samenwerkingsverbanden blijkt echter een gevoelig en ingewikkeld terrein. De voor de samenwerking benodigde informatie bestaat veelal 
uit persoonsgegevens. De consequentie is dat op het verstrekken en gebruiken van informatie een complexe wettelijke materie van toepassing is, zoals deze besloten ligt in de Wet bescherming persoonsgegevens, de Wet politiegegevens, de Wet strafvorderlijke en justitiële gegevens, De Algemene Wet Rijksbelastingen en voorzieningen over het verstrekken en gebruiken van persoonsgegevens in bijzondere wettelijke regelingen. Deze regelingen hebben het karakter van een lappendeken; zij geven voor de verschillende verstrekkers en gebruikers van persoonsgegevens voorschriften die niet goed op elkaar aansluiten. Om wegwijs te worden in de materie, of althans de weg niet kwijt te raken, zijn in de praktijk dikke instructies en handleidingen nodig. ${ }^{70}$ Het gevolg is dat het bepaald niet eenvoudig is om te overzien of in een zeker samenwerkingsverband bepaalde gegevens tussen de samenwerkende partners al dan niet mogen worden uitgewisseld en of die gegevens al dan niet verder mogen worden gebruikt. Dit maakt de samenwerking voor een geïntegreerde rechtshandhaving nodeloos gecompliceerd. De praktijk is gediend met een vereenvoudiging en uniformering van de regelgeving over het uitwisselen en gebruik van persoonsgegevens in samenwerkingsverbanden. Vrij recent is voor de bestrijding van fraude betreffende de sociale zekerheid, inkomensafhankelijke voorzieningen en de belastingen een wettelijk kader gecreëerd voor de gegevensuitwisseling en het effectief gebruik van binnen de overheid bekend zijnde gegevens. ${ }^{71}$ Naar mijn oordeel is niet slechts voor de bestrijding van fraude een voorziening voor gegevensuitwisseling op zijn plaats. Een moderne rechtshandhaving maakt samenwerking tussen publieke en private organisaties noodzakelijk. Mijn voorstel is dan ook dat de wetgever voor deze materie in het verband van de modernisering van het Wetboek van Strafvordering een algemene regeling creëert.72

70 Zie TK 2008/og, 29 911, nr. 23, Brief inzake vragen m.b.t. onderzoek knelpunten informatieuitwisseling bij bestrijding verwevenheid onder- en bovenwereld; WBOM, Diverse juridische aspecten van informatieverstrekking aan de politie en het OM in samenwerkingsverbanden, Den Haag 2011; Openbaar Ministerie, Handreiking informatie-uitwisseling OM in samenwerkingsverbanden.

71 Zie de Wet van 9 oktober 2013, Stb. 405, nader uitgewerkt bij Besluit van 1 september 2014, Stb. 320, tot wijziging van het Besluit SUWI in verband met regels voor fraudeaanpak door gegevensuitwisselingen en het effectief gebruik van binnen de overheid bekend zijnde gegevens met inzet van Syri.

72 Zie ook de aanbevelingen van A.J.C. de Moor-van Vugt e.a., Gegevensuitwisseling door toezichthouders, WODC/UvA 2012, p. 96 en R.W. van Kralingen \& J.E.J. Prins, Waar een wil is, is een weg?, Den Haag: SDU 1996. 
Samenwerking over de landsgrenzen

De noodzaak van samenwerking bij de rechtshandhaving houdt niet op bij de landsgrenzen. Deze mededeling heeft veel weg van het intrappen van een open deur. Zeker in deze Euregio rond Rijn en Maas worden nut en noodzaak van grensoverschrijdende samenwerking door politie en justitie gevoeld. Voor de internationale politiële en justitiële samenwerking bevatten veel Verdragen en het recht van de EU de nodige rechtsinstrumenten. Naast vormen van klassieke rechtshulp kennen wij tegenwoordig bijv. de uitwisseling van informatie tussen politiediensten en een breed scala aan justitiële samenwerkingsmogelijkheden in de EU op basis van het concept van de wederzijdse erkenning. Ondanks deze variëteit aan mogelijkheden blijkt de praktijk van de grensoverschrijdende samenwerking bij de criminaliteitsbestrijding een weerbarstige materie te zijn. Terwijl landsgrenzen voor de burger bij het vrij verkeer van personen binnen de EU nog slechts een symbolische betekenis hebben, zijn diezelfde landsgrenzen voor politie en Openbaar Ministerie nog steeds, soms zelfs onneembare, barrières voor een adequate rechtshandhaving. Ik geef twee voorbeelden. In een onderzoek in de grensstreek naar woninginbraken kan het van belang zijn om bij de autoriteiten aan de andere zijde van de grens na te vragen of de verdachte aldaar bekend is. De vraag is eenvoudig van aard, maar het verkrijgen van een antwoord bepaald niet. Het tweede voorbeeld betreft het internationale betalingsverkeer. Met spreekwoordelijke drie drukken op een knop is het voor de burger mogelijk om wereldomspannende financiële transacties te verrichten. In een strafprocedure kan het van belang zijn om zicht te krijgen op het spoor van die transacties door van banken gegevens over de houders van bankrekeningen en details aangaande de transacties te vorderen. In de richting van bancaire instellingen die in het buitenland zijn gevestigd, wordt dat met gebruikmaking van de bestaande rechtshulpinstrumenten een zeer tijdrovende aangelegenheid. Hierbij moet men dan niet denken in termen van maanden maar van jaren.

De moeizaamheid van de internationale samenwerking heeft tot gevolg dat daders van strafbare feiten landsgrenzen kunnen gebruiken om zich onzichtbaar te maken voor politie en justitie en zich zo onttrekken aan opsporing en vervolging. Om dit risico te verminderen, zal moeten worden gezocht naar mogelijkheden om de internationale politiële en justitiële samenwerking te versnellen en vereenvoudigen. Hier ligt een dankbare taak voor Nederland als komend voorzitter van 
de Raad van de EU. Inspiratie voor ontwikkelingsrichtingen kan worden opgedaan in een rapport van het Bureau Euregionale Samenwerking van het arrondissementsparket Limburg. ${ }^{73}$ Dit rapport bevat uiteenlopende aanbevelingen ter verbetering van de internationale samenwerking. De aanbevelingen zijn gebaseerd op praktijkervaringen van medewerkers van politie en justitie met de grensoverschrijdende samenwerking. Voor een deel kunnen deze aanbevelingen binnen de bestaande juridische kaders worden gerealiseerd, voor het andere deel zal het nodig zijn nieuwe kaders te creëren. Voor een meer effectieve grensoverschrijdende criminaliteitsbestrijding lijkt mij dat onontkoombaar.

Rechterlijke toetsing van de vervolgingsbeslissing

Samenwerking, de afstemming van het beleid van het Openbaar Ministerie met het centrale en decentrale bestuurlijke handhavingsbeleid en het delen van verantwoordelijkheid voor de geïntegreerde rechtshandhaving brengen mij bij het tweede onderwerp. Dat gaat over de verhouding tussen het Openbaar Ministerie en de strafrechter, meer specifiek de toetsing van de vervolgingsbeslissing door de rechter ter zitting. Ten aanzien van de omvang van deze toetsingsbevoegdheid is in de wetgeving en rechtspraak het lang gevestigde uitgangspunt, dat de rechter zich buigt over de juridisch-technische haalbaarheid van de vervolging overeenkomstig de vraagpunten van de art. 348 en 350 Sv en zich heeft te onthouden van een oordeel over de opportuniteit van de vervolging. Naar geldend recht is het aan de officier van justitie voorbehouden om te bezien of een strafvervolging door het algemeen belang wordt vereist. In relatie tot wat Buruma 'flutzaken' heeft genoemd, is getracht verandering te brengen in dit uitgangspunt. Met 'flutzaken' doelt Buruma op lichte strafbare feiten, die in de concrete verschijningsvorm te verwaarlozen zijn en ten aanzien waarvan moet worden getwijfeld of strafvervolging enig doel dient. Volgens Buruma moet de rechter in dergelijke gevallen de mogelijkheid worden geboden 'om een oordeel over de onzinnigheid van een vervolging te laten uitspreken'. 74

73 ie het rapport van het Bureau voor Euregionale samenwerking van het arrondissementsparket Limburg, BES Practice. A practitioner's view on judicial cooperation in criminal matters in EU border regions, Maastricht 2014.

74 Y. Buruma, 'Flutzaken: een pleidooi voor rechterlijke toetsing van vervolgingsbeslissingen', DD 2006, p. 364 e.v. 
Dat oordeel kan er toe leiden dat de officier van justitie niet-ontvankelijk wordt verklaard in de ingezette strafvervolging..$^{75}$

De gedachte van Buruma heeft geen ingang gevonden in de rechtspraak. In de zaak die leidde tot HR 6 november 2012, NJ 2013, 109, m.nt. Schalken, was in feitelijke aanleg het verweer gevoerd dat het Openbaar Ministerie niet-ontvankelijk moest worden verklaard in de vervolging, omdat het volgens de verdediging om een aantal redenen niet tot een strafvervolging had mogen komen. Het hof ging mee met dit verweer en verklaarde het Openbaar Ministerie niet-ontvankelijk in de ingestelde strafvervolging. De beslissing tot vervolging zou volgens het hof niet het resultaat zijn van een redelijke en billijke belangenafweging. Hierdoor zou het Openbaar Ministerie hebben gehandeld in strijd met beginselen van een goede procesorde. De Hoge Raad vernietigde de beslissing van het hof en bevestigde het oude uitgangspunt, dat de rechter niet heeft te oordelen over de opportuniteit van de vervolging. Slechts in het kader van het verbod van willekeur bestaat enige ruimte voor een inhoudelijke - tot de rechtmatigheid van de beslissing beperkte - rechterlijke toetsing van de vervolgingsbeslissing. De Hoge Raad overwoog:

'In art. 167, eerste lid, Sv is ... aan het openbaar ministerie de bevoegdheid toegekend zelfstandig te beslissen of naar aanleiding van een ingesteld opsporingsonderzoek vervolging moet plaatsvinden. De beslissing om tot vervolging over te gaan leent zich slechts in zeer beperkte mate voor een inhoudelijke rechterlijke toetsing in die zin dat slechts in uitzonderlijke gevallen plaats is voor een niet-ontvankelijkverklaring van het openbaar ministerie in de vervolging op de grond dat het instellen of voortzetten van die vervolging onverenigbaar is met beginselen van een goede procesorde, voor zover hier van belang met het verbod van willekeur - dat in strafrechtspraak in dit verband ook wel wordt omschreven als het beginsel van een redelijke en billijke belangenafweging - om de reden dat geen redelijk handelend lid van het openbaar ministerie heeft kunnen oordelen dat met (voortzetting van) de vervolging enig door strafrechtelijke handhaving beschermd belang gediend kan zijn.' 76

75 Zie voor een al wat oudere suggestie in die richting: Gt.J.M. Corstens, Waarborgen rondom het vervolgingsbeleid, Vermande Zonen Uitgevers: IJmuiden 1974, p. 142-143.

76 Zie HR 15 oktober 2013, ECLI:NL:HR:2013:947, waarin voor de vervolgingsbeslissing door een politieparketsecretaris hetzelfde criterium werd aangelegd. Over dit criterium: J. Lindeman, 'Redelijk handelende officieren en de vervolgingsbeslissing', in: C. Kelk e.a. (red.), Veelzijdige gedachten. Liber amicorum Chrisje Brants, BOOM/Lemma, Den Haag 2013, p. 283-295. 
De beginselen van een goede procesorde maken een rechtmatigheidstoetsing van de vervolgingsbeslissing mogelijk, maar bij de vraag of er sprake is van willekeur, is het criterium voor diskwalificatie van de vervolgingsbeslissing erg streng. De gevallen waarin 'geen redelijk handelend lid van het openbaar ministerie' tot de beslissing kon komen, zullen niet vaak voorkomen, alleen al omdat het Openbaar Ministerie toch voornamelijk uit redelijk handelende mensen bestaat.77

De modernisering van het Wetboek van Strafvordering was voor Buruma aanleiding om opnieuw aandacht te vragen voor ruimte voor de rechter voor een inhoudelijke toetsing van de vervolgingsbeslissing, die verder gaat dan een toetsing op basis van de beginselen van een goede procesorde. Hij nodigt de ontwerpers van het nieuwe wetboek uit om na te denken over een wettelijke voorziening op basis waarvan de rechter zou kunnen toetsen 'of in het individuele geval is vervolgd met miskenning van het beleid' of dat de 'rechter tot niet-ontvankelijkheid van het OM in de vervolging zou moeten kunnen oordelen indien de verwijtbaarheid van de verdachte gering is en niet een algemeen belang wordt gediend met vervolging ${ }^{\prime}{ }^{78}$ Verschillende overwegingen brengen Buruma ertoe om de wenselijkheid van een dergelijke toetsingsmogelijkheid te bepleiten. Kort weergegeven hebben deze betrekking op het gegeven dat het tot op heden in de rechtspraak gehuldigde uitgangspunt tot stand is gekomen in een institutioneel kader dat niet vergelijkbaar is met de huidige strafrechtspleging, de politisering van het beleid van het Openbaar Ministerie en het gegeven dat veel vervolgingsbeslissingen, vooral in lichte zaken, worden genomen door andere functionarissen dan officieren van justitie. ${ }^{79 / 80}$

77 Zie voor een bijzonder geval waarin de officier van justitie niet-ontvankelijk werd verklaard: HR 7 januari 2014, ECLI:NL:HR:2014:15.

78 Y. Buruma, 'Rechterlijke controle op de vervolgingsbeslissing', Strafblad 2015/45.

79 Zie ook Y. Buruma, Jaarrede NJV, NJB 2014, 27, p. 1837, waar hij aangeeft het wenselijk te vinden de rechter toe te staan 'bijvoorbeeld na een kennelijk onredelijke vervolgingsbeslissing (denk aan standaardwerkwijzen in het vooronder van het OM) de officier niet ontvankelijk te verklaren'.

80 Een ruimere toetsing van de vervolgingsbeslissing is ook bepleit door A.A. Franken, 'De kosten van de strafvordering en de kosten van detentie', DD 2015/42 en 'Afstand houden. Over samenwerking tussen rechter en openbaar ministerie en samenwerking tussen rechter en wetgever', $D D$ 2014/24. De argumenten die in de genoemde publicaties een ruimere toetsing wenselijk zouden maken, vind ik - om het maar zacht te zeggen - ver gezocht. Met een ruimere toetsing zou moeten worden 'voorkomen dat de beslissing tot dagvaarding, al dan niet na zacht aandringen van de Minister, mede op financiële gronden wordt genomen' (DD 2015, p. 434), en: 'bepalingen in het landelijk procesreglement en de wijze van financiering van de gerechten kunnen meebrengen dat zaken ter zitting aan de orde komen die nooit de fase van het onderzoek ter terechtzitting hadden mogen bereiken' (DD 2014, p. 260). 
Ik kan mij vinden in het betoog van Buruma. In het huidige tijdsgewricht, met een nauwe band tussen minister van V\&J en Openbaar Ministerie en een verwevenheid van het strafrechtelijke beleid met het centrale en decentrale bestuurlijke criminaliteitsbeleid, vind ik het een positief te waarderen ontwikkeling als de strafrechter in een individuele strafzaak tot op zekere hoogte de vervolgingsbeslissing ruimer dan alleen aan de beginselen van een behoorlijke procesorde zou mogen toetsen. Aan de argumenten die Buruma tot zijn standpunt brachten, wil ik nog een overweging toevoegen. In een 'geïntegreerde aanpak' van uiteenlopende vormen van criminaliteit zijn strafrechtelijke interventies het resultaat van samenwerking tussen Openbaar Ministerie en andere publieke en private organisaties. De afstemming van het bestuurlijke en het strafrechtelijke beleid wordt beschouwd als een gedeelde verantwoordelijkheid. Het Openbaar Ministerie is, zo valt in Perspectief op 2015 te lezen, bereid om bij die afstemming rekening te houden met 'prioriteiten en strategieën' van het openbaar bestuur. ${ }^{81}$ De consequentie hiervan is dat, zoals De Doelder het heeft verwoord, het opportuniteitsbeginsel wordt gebruikt om 'politieke beleidsregels' te effectueren. ${ }^{82}$ Deze verbinding tussen politiek en strafrecht maakt het, naast de door Buruma genoemde argumenten, naar mijn oordeel wenselijk de door de strafrechter te bieden rechtsbescherming te verruimen.

De uitvoering van het voorstel van Buruma zal voor de ontwerpers van het gemoderniseerde wetboek geen eenvoudige klus zijn. Bij de redactie van een criterium op basis waarvan de strafrechter de vervolgingsbeslissing zou kunnen toetsen, moet voorop staan dat de strafrechter niet geroepen kan zijn tot een inhoudelijk volledige toetsing van de opportuniteit van de vervolging. Het zal moeten gaan om een beoordeling van de vervolgingsbeslissing in het individuele geval tegen de achtergrond van het gevoerde beleid. Deze beoordelingsmogelijkheid moet toetsingsruimte toevoegen aan een thans al mogelijke toetsing van de vervolgingsbeslissing aan de hand van de beginselen van een behoorlijke procesorde. Nu bij de opportuniteitsafweging het

81 Zie in dit verband W.J.V.van der Spek, 'Het opportuniteitsbeginsel en de ultimum remedium-gedachte', Strafblad 2010, p. 230: '... het Openbaar Ministerie zich niet eigengereid kan opstellen en vervolgen zoals het hem goed dunkt zonder rekening te houden met het door andere delen van de overheid gevoerde beleid. Het mag niet zo zijn dat het vervolgingsbeleid als het ware in de lucht komt te hangen noch dat het een beleid dat uiteindelijk onder democratische controle staat, doorkruist'.

82 H. de Doelder, De onafhankelijke strafrechter, Erasmus law lectures 34, BJu: Den Haag 2014, p.9-10. 
algemeen belang leidend is, biedt het negatieve, het ontbreken van belang, een aanknopingspunt voor toetsing door de rechter. In deze benadering zou het Openbaar Ministerie in de strafvervolging nietontvankelijk kunnen worden verklaard, als met de vervolging van de zaak in redelijkheid geen maatschappelijk belang is gediend. Een dergelijk criterium laat het Openbaar Ministerie voldoende afwegingsvrijheid en biedt de rechter de mogelijkheid om echt onzinnige vervolgingen af te kappen. Bijkomend voordeel van een op het maatschappelijk belang bij vervolging toegespitst criterium is dat de rechter niet expliciet hoeft te oordelen over de wijze waarop de officier van justitie tot zijn afweging is gekomen. ${ }^{83}$ De rechter kan zich beperken tot een beoordeling van de vervolging in het individuele geval, zonder de vervolgingsbeslissing te moeten toeschrijven aan iemand die 'geen redelijk handelend lid van het openbaar ministerie' mag worden genoemd.

\section{Bezinning op het takenpakket van het Openbaar Ministerie}

Het volgende onderwerp dat ik aan de orde wil stellen, betreft het takenpakket van het Openbaar Ministerie. Zoals eerder aangegeven, brengen reorganisatie en bezuinigingstaakstelling mee dat er spanning bestaat tussen de voor de uitvoering van taken gewenste en de feitelijk beschikbare capaciteit, met als gevolg dat de kwaliteit van de rechtshandhaving onder druk staat. Omdat de stand van de overheidsfinanciën geen perspectief op vergroting van de capaciteit bieden, valt te overwegen om het takenpakket van het Openbaar Ministerie te reduceren. Dat zou meebrengen dat capaciteit vrijkomt voor de bevordering van de kwaliteit van de rechtshandhaving. In het kader van een van de onderdelen van het programma VPS is al sprake van zo' $n$ reductie. Deze ligt besloten in het Wetsvoorstel Herziening tenuitvoerlegging strafrechtelijke beslissingen. ${ }^{84}$ Uitgangspunt van dit wetsvoorstel is dat taken aangaande de tenuitvoerlegging van strafrechtelijke beslissingen worden overgeheveld van het Openbaar Ministerie naar de minister van V\&J. Mevis heeft er zijn verbazing over uitgesproken dat het Openbaar Ministerie 'zich de zeggenschap over de tenuitvoerlegging van straf en maatregel in concrete zaken

83 Impliciet natuurlijk wel, maar die beoordeling is niet anders dan bij een afwijkend oordeel van de rechter over bijv. het bewijs of de strafmaat.

84 Zie voor het wetsvoorstel TK 2014/15, 34 086, nr. 2. 
geheel laat ontnemen'.85 Zo verbazingwekkend vind ik dat echter niet. Thans is de tenuitvoerlegging van strafrechtelijke beslissingen feitelijk in belangrijke mate al toevertrouwd aan uitvoeringsdiensten van het ministerie van V\&J en is de bemoeienis van het Openbaar Ministerie met de daadwerkelijke tenuitvoerlegging beperkt. In de kern krijgt met het wetsvoorstel deze stand van zaken neerslag in het wetboek. Voorts weegt voor mij mee, dat de executietaak van het Openbaar Ministerie in theorie weliswaar tot de kerntaken hoort, maar in de praktijk de status heeft van stiefkindje. Zodra in een periode spanning ontstaat tussen de te verrichten taken en de daarvoor beschikbare capaciteit, wordt alle aandacht gericht op het primaire werkproces. Secundaire taken zoals de tenuitvoerlegging staan dan op het tweede plan. Om deze redenen waardeer ik de herschikking van verantwoordelijkheden aangaande de tenuitvoerlegging positief. ${ }^{86}$ Het toedelen van executietaken aan de minister brengt mee dat het takenpakket van het Openbaar Ministerie wordt verkleind en dat de capaciteit voor de primaire processen wordt vergroot. Bijkomend voordeel voor het Openbaar Ministerie is dat het is verlost van de verantwoordelijkheid voor een politiek netelige portefeuille.

In het verlengde van de herschikking van de executietaken komt de vraag op of ook andere onderdelen van het takenpakket van het Openbaar Ministerie vatbaar zijn voor herschikking. Een wat radicale gedachte is om taken van het Openbaar Ministerie te privatiseren. Sweder van Wijnbergen vond dit niet een bij voorbaat af te wijzen mogelijkheid. Hij achtte het niet uitgesloten om werkzaamheden van het Openbaar Ministerie toe te vertrouwen 'aan het advocatenkantoor dat de beste kwaliteit levert' ${ }^{87}$ Gedacht zou bijvoorbeeld kunnen worden om, in het verlengde van privatisering van de opsporing, onderdelen van de vervolgingstaak uit te besteden aan particuliere advocaten.

In een reactie op de gedachte van Sweder van Wijnbergen heeft Buruma de argumenten geïnventariseerd die een rol spelen bij de vraag of privatisering van de vervolgingstaak aanvaardbaar kan worden bevonden. ${ }^{88}$ In zijn betoog onderscheidt hij een drietal categorieën

85 P.A.M. Mevis, 'Modernisering strafvordering', in: DD 2014/55, p. 580.

$86 \mathrm{Vgl}$. het preadvies van G. Duisterwinkel voor de NJV, Vereisen de functies van het Openbaar Ministerie nieuwe wettelijke voorzieningen?, p. 235; Duisterwinkel ziet voor het Openbaar Ministerie geen taak meer weggelegd bij de tenuitvoerlegging van strafvonnissen.

87 Zie 'Van Wijnbergen doceert. Een blauwdruk voor de privatisering', NRC 23 september 1999.

88 Y. Buruma, 'Privatisering van het openbaar ministerie', in: NJB 1999, p. 1886-1889. 
argumenten: de praktische voordelen van privatisering, rechtsstatelijke uitgangspunten en de maatschappelijke context. Van dit drietal werpen de rechtsstatelijke uitgangspunten het meeste gewicht in de schaal. Buruma beschouwt de strafrechtelijke rechtshandhaving als een publieke taak die slechts kan worden uitgevoerd door een publieke autoriteit. Dit baseert hij op de ministeriële verantwoordelijkheid en het gegeven dat rechtshandhaving inhoudelijk meer is dan een efficiënte en effectieve wetshandhaving. Hij ziet ook een principieel verschil in de gerichtheid van het professionele handelen van de officier van justitie en de advocaat. In de woorden van Buruma: 'een officier van justitie (staat) voor principiële belangenloosheid ... - het gaat om rechtshandhaving terwijl de professionele opdracht van een advocaat is, dat hij werkt voor een cliënt. Het oog voor het algemeen belang vergt een andere instelling (cultuur, attitude) dan het oog voor het belang van de opdrachtgever'. verdere overwegingen aangaande het dienen van het algemeen belang, de legitimiteit van strafrechtelijke beslissingen en procedurele kwaliteit brengen hem tot het standpunt dat het vervolgingsrecht in handen van het Openbaar Ministerie moet blijven.

Een variant op het voorgaande is bepleit door De Lange. ${ }^{89} \mathrm{Hij}$ meent dat het vervolgingsmonopolie van het Openbaar Ministerie moet worden losgelaten en dat aan bestuurlijke autoriteiten een recht op toegang tot de strafrechter moet worden verleend. Dit vervolgingsrecht zal dan niet zelfstandig kunnen worden uitgeoefend, maar alleen in het kader van samenwerking met het Openbaar Ministerie. Die samenwerking bij de vervolging kan in verschillende modellen worden gegoten. De Lange spreekt over een accessoire variant en een duale variant van het samenwerkingsmodel. Hij ziet het delen van de vervolgingsbevoegdheid door het Openbaar Ministerie als een 'strategische terugtocht' die strekt tot wederzijds voordeel. Enerzijds kan het Openbaar Ministerie in de samenwerking profiteren van kennis, ervaring en onderzoekscapaciteit bij het bestuursorgaan op een bijzonder terrein van de ordeningswetgeving en anderzijds kan het bestuursorgaan de handhaving van de betrokken

89 A. de Lange, 'De strategische terugtocht van een monopolist', Strafblad 2010, p. 176-193; zie ook zijn bijdrage 'De terugkeer van de bestuurlijke partij in het strafproces', in: A.H.E.C. Jordaans e.a. (red.), Praktisch Strafrecht. Liber amicorum J.M. Reijntjes, WLP: Nijmegen 2005, p. 417-436, en: 'Een strategische terugtocht van het Openbaar Ministerie. Een opstel over de positie van het Openbaar Ministerie en andere partijen in het strafproces', in: E. Bleichrodt e.a. (red.), Onbegrensd strafrecht. Liber amicorum Hans de Doelder, WLP: Oisterwijk 2013, p. 
wetgeving verstevigen. Het Openbaar Ministerie kan zich op deze wijze concentreren op de rechtshandhaving, op een beheerste en evenwichtige toepassing van het strafrecht, en het bestuursorgaan op de ongedaanmaking van het geschonden rechtsgoed.

In dit voorstel van De Lange blijft het recht tot strafvervolging een publiekrechtelijke aangelegenheid. En een belangrijke beperking is dat het bestuursorgaan zich niet zelfstandig tot de strafrechter kan wenden, maar uitsluitend in een vorm van samenwerking met het Openbaar Ministerie. Bij zijn voorstel moet worden bedacht dat thans met de bestuurlijke strafbeschikking van art. 257 ba Sv al aan bestuursorganen een beperkt vervolgingsrecht is toegekend. Desondanks meen ik dat de monopoliepositie van het Openbaar Ministerie ten aanzien van de toegang tot de strafrechter moet worden gehandhaafd. Mijn bezwaren tegen het toekennen van een (ook onzelfstandig uit te oefenen) vervolgingsrecht aan bestuursorganen houden in de kern verband met de positie van de officier van justitie in het strafproces, met name het uitgangspunt dat de officier geen procespartij is en oog moet hebben voor alle bij de zaak betrokken belangen. Een tot de strafvordering gerechtigd bestuursorgaan acteert in het kader van de handhaving van een onderdeel van de ordeningswetgeving met zorg voor herstel van het geschonden rechtsgoed. Hierin ligt besloten dat het bestuursorgaan in de strafvervolging opkomt voor bijzondere aan hem toevertrouwde rechtsbelangen. Uiteindelijk maken dezelfde argumenten die zich verzetten tegen privatisering van het recht tot strafvervolging het voor mij ook onwenselijk om een vervolgingsrecht toe te kennen aan bestuursorganen. Een bijkomend argument is dat de praktische noodzaak voor het loslaten van het vervolgingsmonopolie ontbreekt. In het kader van de geïntegreerde rechtshandhaving bestaan er allerlei samenwerkingsverbanden tussen het Openbaar Ministerie en bestuursorganen. In die verbanden kan het Openbaar Ministerie gebruik maken van de expertise en informatie die bij andere handhavingsinstanties aanwezig is. In die samenwerking moet met name het Functioneel Parket met het sanctiearsenaal uit het Wetboek van Strafrecht en de Wet Economische Delicten op adequate wijze vorm kunnen geven aan de strafvervolging, zonder dat processuele bijstand van een bestuursorgaan nodig is.

In de discussie over de taken van het Openbaar Ministerie is gesuggereerd de centrale rol van de organisatie in het strafproces te beperken. In het bijzonder is de vraag opgeworpen of het Openbaar Ministerie de zeggenschap over de opsporing moet behouden. In de toekomstige 
strafvordering zou de verantwoordelijkheid voor de opsporing wellicht aan de politie moeten worden gelaten. De taak van het Openbaar Ministerie zou dan moeten worden beperkt tot het beoordelen en afdoen van de strafzaken die door de politie zijn aangeleverd. Vreemd is deze gedachte niet, omdat ook in Engeland en Duitsland de CPS en de Staatsanwaltschaft geen zeggenschap hebben over de politie.

Een verzelfstandiging van de politie ten aanzien van de opsporing levert voor het Openbaar Ministerie ongetwijfeld capaciteitswinst op. Bovendien wordt dan een bron van strijd tussen Openbaar Ministerie en politie weggenomen, namelijk het vaststellen van prioriteiten aangaande de inzet van opsporingscapaciteit. Toch is het om verschillende redenen verstandig om de zeggenschap over de opsporing in handen te laten van het Openbaar Ministerie. Het eerste argument hangt samen met de reikwijdte van het opportuniteitsbeginsel en de regie over de strafrechtsketen. De zeggenschap over de opsporing in combinatie met het opportuniteitsbeginsel geven het Openbaar Ministerie de mogelijkheid om de opsporing in meerdere opzichten te sturen. Zo kan invloed worden uitgeoefend op de keuze van delicten waaraan opsporingscapaciteit moet worden besteed en kunnen omvang en onderwerp - welke verdachten, welke delicten? - van het onderzoek worden beheerst. Op deze wijze kan het Openbaar Ministerie de totale werkstroom in de strafrechtsketen sturen, kan worden voorkomen dat fricties ontstaan en kan een evenwichtige strafrechtsbedeling worden bevorderd.

Het tweede argument betreft de controle over de rechtmatigheid en volledigheid van het opsporingsonderzoek. Deze controle is onmogelijk als het Openbaar Ministerie geen zeggenschap heeft over de opsporing. De consequentie is dat in het strafprocesrecht ter compensatie voorzieningen moeten worden ingebouwd, waarmee controle over het werk van de politie mogelijk wordt gemaakt. Dat vereist in ieder geval bijzondere voorzieningen in relatie tot de samenstelling van het procesdossier, zowel voor het Openbaar Ministerie als de verdediging. Ook zou de betekenis van vormvoorschriften voor de opsporing en de sanctionering van vormverzuimen moeten worden heroverwogen. Als ik de voor- en nadelen van de zeggenschap van het Openbaar Ministerie over de opsporing afweeg, meen ik dat de balans doorslaat richting behoud van die zeggenschap..$^{\circ}$ Ten behoeve van de noodzakelijke prioriteitenstelling en afbakening van de opsporing ligt 'de kerntaak 
van het $\mathrm{OM}$ in heden, verleden en toekomst onomstreden in de betrokkenheid van dit orgaan als leider van de opsporing', zo stelt Mevis naar mijn oordeel terecht.91

Naast de gezagsstructuren in het Wetboek van Strafvordering biedt de Politiewet 2012 aan het Openbaar Ministerie enkele mogelijkheden om invloed uit te oefenen op het beheer, de toedeling van capaciteit en het beleid van de politie. In het geheel zijn die mogelijkheden voor het Openbaar Ministerie te zwak om bij onenigheid over de gewenste richting van de opsporing de bij zeggenschap horende beslissingsmacht uit te oefenen. In dit opzicht kan de positie van het Openbaar Ministerie worden versterkt door aan het Openbaar Ministerie beslissingsmacht over een deel van het politiebudget toe te kennen. Zeggenschap over de besteding van middelen ten behoeve van de opsporing leidt ertoe dat de politiecapaciteit beter kan worden gestuurd in de door het Openbaar Ministerie gewenste richting.

\section{Vormverzuimen en toezicht op de opsporing}

Het laatste onderwerp dat ik wil belichten betreft het toezicht over de opsporing en de sanctionering van vormverzuimen. Dit is een thema dat in de Contourennota wel wordt aangestipt, maar inhoudelijk onbesproken is gebleven. Over dit onderwerp hebben de minster wisselende adviezen bereikt. De Contourennota geeft aan dat hij op basis van deze adviezen een nader standpunt zal innemen na afronding van wetenschappelijk onderzoek naar mogelijke toezichtsmechanismen. ${ }^{92}$ Een van de aandachtspunten hierbij is de vraag 'of in het wetboek een nadere uitwerking kan worden opgenomen van de bijzondere verantwoordelijkheid die het College van procureurs-generaal heeft voor het toezicht op de richtige opsporing en vervolging. ${ }^{9} 93$

Het belang van de vraag naar vormen van toezicht over de opsporing is opgekomen in het licht van een tweetal ontwikkelingen. De eerste ontwikkeling betreft de stand van de rechtspraak van de Hoge Raad over art. 359a Sv, het wetsartikel waarin is aangegeven welke rechtsgevolgen de strafrechter in zijn vonnis kan verbinden aan de constatering dat in het vooronderzoek vormen zijn verzuimd. De tweede ontwikkeling heeft betrekking op het gebruik van de moderne techniek bij de opsporing, waarbij heimelijk grote hoeveelheden gegevens kunnen

91 P.A.M. Mevis, a.w. (2014), p. 581

92 TK 2015/16, 29 279, nr. 278, Contourennota, p. 19-20.

93

TK 2015/16, 29 279, nr. 278, Contourennota, p. 36. 
worden verzameld. De parallel tussen beide ontwikkelingen is dat het toezicht van de strafrechter over de rechtmatigheid van de opsporing tekort schiet.

\section{Art. 359a Sv: de stand van de rechtspraak}

In 2004 heeft de Hoge Raad een zogenaamd standaardarrest gewezen over de toepassing van art. 359a Sv. ${ }^{94}$ Dit arrest bevat een overzicht van de voorwaarden waaraan volgens de Hoge Raad moet zijn voldaan, wil de strafrechter aan de vaststelling dat in het voorbereidend onderzoek een vorm is verzuimd het rechtsgevolg verbinden dat het Openbaar Ministerie niet-ontvankelijk moet worden verklaard in de vervolging, verkregen bewijsmateriaal niet mag worden gebruikt voor het bewijs of de op te leggen straf moet worden gematigd. In het arrest wordt de strafrechter geïnstrueerd bij de motivering van zijn beslissing aandacht te besteden aan de aandachtspunten van art. 359a lid 2 Sv: bij de waardering van het vormverzuim en het daaraan te verbinden rechtsgevolg moet de rechter letten op 'het belang dat het geschonden voorschrift dient, de ernst van het verzuim en het nadeel dat daardoor wordt veroorzaakt'. De sedert 2004 gewezen rechtspraak over deze materie maakt duidelijk, dat de mogelijkheden voor de strafrechter om consequenties te verbinden aan onrechtmatig opsporend optreden maar heel beperkt zijn. De beslissing dat het Openbaar Ministerie wegens onrechtmatigheden in de opsporing niet-ontvankelijk moet worden verklaard in de vervolging is gereserveerd voor 'uitzonderlijke gevallen'. Uit het arrest van de HR van 9 februari 2013, ECLI:NL:HR:2013:BY5321, NJ 2013/308 volgt dat met grote terughoudendheid moet worden overgegaan tot bewijsuitsluiting. Daarvoor is slechts plaats 'indien het bewijsmateriaal door het verzuim is verkregen, en ... indien door de onrechtmatige bewijsgaring een belangrijk (strafvorderlijk) voorschrift of rechtsbeginsel in aanzienlijke mate is geschonden'. Als sprake is van zo'n schending, kan de rechter om verschillende redenen overgaan tot bewijsuitsluiting. Het uitsluiten van bewijs kan aangewezen zijn om het recht op een eerlijk proces in de zin van art. 6 EVRM te verzekeren, als er sprake is van een zeer ingrijpende inbreuk op een grondrecht van de verdachte of als er sprake is van onrechtmatig optreden dat een structureel karakter heeft. Van dat structurele karakter moet blijken uit objectieve gegevens en de verantwoordelijke autoriteiten - lees: de leiding van de politie en 
het Openbaar Ministerie - moeten zich, 'vanaf het moment waarop dit structurele verzuim hun bekend moet zijn geweest, onvoldoende inspanningen hebben getroost overtredingen van het desbetreffende voorschrift te voorkomen'. Bijkomende voorwaarde is de verwachting dat bewijsuitsluiting 'daadwerkelijk de beoogde normerende werking op de praktijk van opsporing en vervolging zal hebben, waarbij van belang kan zijn wat de oorzaak van het vormverzuim is en wat (reeds) door de verantwoordelijke autoriteiten ter voorkoming van overtreding van het bewuste voorschrift is ondernomen'. Vervolgens moet nog worden afgewogen of de voordelen van bewijsuitsluiting opwegen tegen de negatieve effecten daarvan voor de waarheidsvinding en de bestraffing van de dader van een strafbaar feit. En als aan dit alles is voldaan, moet ook nog aannemelijk zijn dat de verdachte door de schending van het belangrijke strafvorderlijke voorschrift of beginsel 'nadeel' heeft ondervonden in zijn verdediging. Borgers trekt uit deze rechtspraak van de Hoge Raad de conclusie dat de marges voor de strafrechter om te waken over de integriteit van de opsporing 'nogal krap' zijn. Dit brengt volgens hem de noodzaak naderbij om 'alternatieven voor afdoening van vormverzuimen door de strafrechter (nader) te exploreren en te ontwikkelen'.95

\section{Moderne techniek en gegevensvergaring}

De tweede ontwikkeling die onderzoek naar vormen van toezicht over de opsporing wenselijk maakt, heeft betrekking op bevoegdheden waarmee bij de opsporing heimelijk grote hoeveelheden gegevens van verdachten en niet-verdachten kunnen worden verzameld. Ik doel op het onderzoek van telecommunicatie (ook wel de telefoontap en de internettap), het opvragen van verkeersgegevens omtrent het gebruik van telecommunicatie, het opvragen van gegevens over betalingsverkeer, het gebruik van camera's met gezichtsherkenningssystemen en het onderzoek in, en in de toekomst, het binnendringen in geautomatiseerde systemen. De toepassing van dergelijke bevoegdheden is weliswaar met diverse waarborgen omringd, zoals een interne toetsing binnen het Openbaar Ministerie, een beslissing door de officier van justitie, eventueel een machtiging door de rechter-commissaris en notificatie, maar het geheel aan waarborgen is in rechtsstatelijk perspectief te

95 Zie de noot van M.J. Borgers onder HR 4 november 2014, ECLI:NL:HR:2014:3109, NJ 2015, 288. 
fragmentarisch. Hierbij is van belang dat de gegevens die met toepassing van de genoemde bevoegdheden worden verzameld, frequent niet zullen leiden tot een strafzaak of niet van belang zullen zijn voor het bewijs. In die gevallen zal de strafrechter geen oordeel kunnen geven over de rechtmatigheid van de toepassing van die bevoegdheden. Gelet op het heimelijke karakter van de genoemde bevoegdheden, de daarmee te vergaren grote hoeveelheden gegevens en het gebruik dat daarvan kan worden gemaakt, zal het toezicht over de rechtmatigheid van toepassing en wijze van uitvoering van deze bevoegdheden systematisch beter moeten worden verankerd.

\section{Taak van het Openbaar Ministerie}

Het zal u vermoedelijk niet verrassen dat ik meen dat hier een dankbare taak ligt voor het Openbaar Ministerie. Als de strafrechter onvoldoende in staat is om toezicht te houden over de rechtmatigheid van de opsporing, zal het Openbaar Ministerie daarin moeten voorzien..$^{96}$ Een magistratelijke taakopvatting impliceert dat het Openbaar Ministerie heeft in te staan voor de rechtmatigheid van de opsporing en vervolging. ${ }^{97}$ Deze gehoudenheid vraagt in de moderne strafvordering om voorzieningen waarmee niet alleen in individuele strafzaken, maar juist systematisch toezicht kan worden gehouden over de opsporing en de toepassing van opsporingsbevoegdheden. Dit is niet alleen aan de orde bij meer ingrijpende bevoegdheden, maar ook in eenvoudige zaken die veelal buitengerechtelijk worden afgedaan. Het ontbreken van toezicht van de rechter verzwaart de verantwoordelijkheid van het Openbaar Ministerie voor controle over de politie, zo stellen Corstens en Kuiper terecht. ${ }^{98}$ Deze verantwoordelijkheid krijgt extra gewicht als uit een rapport van de Inspectie Veiligheid en Justitie 'Parate kennis bevoegdheden politie' de conclusie kan worden getrokken dat de kennis bij politieambtenaren in de basispolitiezorg over strafvorderlijke

96 Zie in dit verband TK 2015/16, 29 279, nr. 278, Contourennota, p. 107 over de positie Openbaar Ministerie: 'Ten slotte is het wenselijk dat de verantwoordelijkheid van het College van procureurs-generaal voor het toezicht op de richtige opsporing en vervolging het opsporings- en vervolgingsbeleid beter in het wetboek wordt vastgelegd.

97 Vgl. P.M. Frielink, a.w. (2010), p. 10: 'Zo moeten ZM en advocatuur ervan uit kunnen gaan dat het OM staat voor de rechtmatigheid van de opsporing en de fairheid van de vervolging'. 
bevoegdheden tekort schiet.99 De Inspectie spreekt hierover zijn zorg uit, juist omdat het gaat over bevoegdheden die voor deze politieambtenaren tot de dagelijkse toepassingpraktijk horen. ${ }^{100}$

In het licht van de rechtspraak van de Hoge Raad over de redenen die de rechter ertoe kunnen brengen om onrechtmatig politieoptreden te sanctioneren met bewijsuitsluiting bevattehet Advocatenbladvanjanuari 2015 een bijzonder bericht. Onder de titel 'Structurele vormverzuimen in het strafproces' vroeg strafrechtsadvocaat Robert Malewicz naar aanleiding van een voordracht van R. Kuiper op het NVSA-congres ${ }^{101}$ aan zijn vakgenoten om melding te maken van onrechtmatigheden in de opsporing die mogelijkerwijs een structureel karakter hebben. Die informatie zou kunnen worden gebruikt voor de opbouw van verweren waarbij aan de rechter wordt gevraagd aan onrechtmatigheden in de opsporing het rechtsgevolg van bewijsuitsluiting te verbinden. De oproep van Malewicz versta ik als een aanwijzing voor het bestaan van een tekort aan toezicht over de opsporing. Het gestructureerd inventariseren van onrechtmatigheden in de opsporing hoort naar mijn oordeel tot de taken van het Openbaar Ministerie. Met een dergelijke inventarisatie kan het Openbaar Ministerie in overleg met de leiding van de politie en het ministerie van $V \& J$ bezien welke matregelen moeten worden getroffen om de kwaliteit van de opsporing te verbeteren. Op deze wijze kan een hedendaagse invulling worden gegeven aan de taak van het College van Procureurs-Generaal om te waken 'voor de richtige opsporing 'van strafbare feiten (art. $140 \mathrm{~Sv}$ ).

Naast toezicht over de opsporing meen ik dat het Openbaar Ministerie eveneens moet voorzien in systematisch toezicht op de rechtsstatelijke kwaliteit van het eigen functioneren. Dit is met name aan de orde bij die werkzaamheden waar rechterlijk toezicht structureel ontbreekt, zoals de bevoegdheden tot buitengerechtelijke afdoening. In dit verband wijs ik op het onderzoek dat door de P-G bij de Hoge Raad is uitgevoerd naar de praktijk van de strafbeschikking. Het is goed dat dit onderzoek is uitgevoerd, juist omdat het Openbaar Ministerie hier in meerdere opzichten steken heeft laten vallen. Ik doel

\footnotetext{
99 Inspectie Veiligheid en Justitie, Rapport 'Parate kennis bevoegdheden politie', december 2014.

Het betreft de volgende bevoegdheden: staande houden en aanhouden, onderzoek aan kleding en lichaam, binnentreden, doorzoeken, in beslag nemen en identiteitsonderzoek. Zie voor de tekst van deze voordracht: R. Kuiper, 'De nieuwe benadering van vormfouten: 'Mag ik het zo samenvatten?', Strafblad 2015/5.
} 
dan niet op de door de P-G geconstateerde tekortkomingen, maar op het gebrek aan systematische controle over de praktijk van de buitengerechtelijke afdoening door het Openbaar Ministerie zelf. Met Mevis meen ik dat het door de P-G uitgevoerde onderzoek al eerder door het Openbaar Ministerie zelf had moeten worden verricht. ${ }^{102}$ Andere kwesties waarop het toezicht betrekking kan hebben, zijn bijvoorbeeld de naleving van de notificatieplicht die geldt voor diverse heimelijke opsporingsbevoegdheden, de wijze waarop gevolg wordt gegeven aan de door het hof gegeven bevelen tot vervolging in het kader van art. 12 Sv en de praktijk van de bestuurlijke strafbeschikking. Met systematisch toezicht door het Openbaar Ministerie over de rechtmatigheid van opsporing en vervolging kan de kwaliteit van de strafrechtsbedeling worden bewaakt en bevorderd. Bovendien kan een dergelijk systeem van toezicht bijdragen aan het vertrouwen in een deugdelijke taakuitoefening door het Openbaar Ministerie en zo bijdragen aan de legitimiteit van de organisatie en, breder, van de strafrechtelijke rechtshandhaving.

\section{Afronding}

Reorganisaties en forse bezuinigingen, het zijn moeilijke tijden voor het Openbaar Ministerie. De organisatie draait al enige tijd op de toppen van zijn kunnen en van de medewerkers worden stevige inspanningen en offers gevraagd om kwantitatieve taakstellingen te realiseren. Een complicerende factor in dit geheel is dat het Openbaar Ministerie bij de uitvoering van zijn taken sterk afhankelijk is van het presteren van de politie, NFI, NIFP en zittende magistratuur. En die blijken door dezelfde verschijnselen ook lastige tijden door te maken. Daar heeft het Openbaar Ministerie in de dagelijkse praktijk gewoon last van.

Het leveren van topprestaties en stevige inspanningen is collectief en individueel enige tijd vol te houden, maar op gegeven moment komen de grenzen van het presterend vermogen in zicht. Mijn impressie is dat die grenzen dicht zijn genaderd en bij ongewijzigd (bezuinigings) beleid gaan worden overschreden. Het functioneren van de organisatie komt dan in een gevarenzone, waarbij brokken in de primaire processen haast onvermijdelijk zijn. Ik roep de waarschuwende woorden van de Galan Groep in herinnering.

In de aanloop naar de actuele situatie zijn rechtsstatelijke kernwaarden aangaande de taakuitoefening door het Openbaar 
Ministerie in de verdrukking geraakt. In de rechtsstatelijke waakzaamheid en een magistratelijke taakopvatting ligt echter naar mijn overtuiging de primaire legitimatie voor het bestaan van het Openbaar Ministerie en het aan de organisatie toevertrouwde vervolgingsmonopolie. Tegelijkertijd zijn de rechtsstatelijke waakzaamheid en magistratelijke taakopvatting belangrijke waarborgen rondom de centrale rol van de officier van justitie in het strafproces. Wil het Openbaar Ministerie zijn bestaansrecht op de langere termijn niet ondergraven, dan zal de organisatie moeten laten zien dat rechtstatelijke waakzaamheid en magistratelijke taakopvatting werkelijk betekenis hebben in de dagelijkse praktijk bij de afdoening van strafzaken. Dat lijkt mij de komende jaren een mooie, maar ook uitdagende opdracht.

\section{Slotwoord}

Mijnheer de Rector Magnificus, dames en heren,

Aan het eind gekomen van mijn rede wil ik graag nog een kort dankwoord uitspreken. Mijn eerste dank gaat uit naar u allen in deze zaal. Beste mensen, ik vind het een hele eer dat $u$ in zo groten getale voor het aanhoren van mijn verhaal naar het zuiden heeft willen afreizen. Ik dank u voor uw komst.

Voorts wil ik nog enige persoonlijke woorden richten tot enkelen onder u. Dat is op de eerste plaats gericht aan het College van Bestuur van deze universiteit en het College van Procureurs-Generaal. Ik ben u zeer erkentelijk voor mijn benoeming op de bijzondere leerstoel Openbaar Ministerie. Met deze leerstoel wordt het belang van academische aandacht voor het belangrijke en mooie werk van het OM onderstreept.

Een volgend woord van dank richt ik tot twee personen die een onmisbare bijdrage hebben geleverd aan mijn juridische vorming. Mijn promotor, hooggeleerde Groenhuijsen, beste Marc, ik denk nog steeds met veel genoegen terug aan onze samenwerking tijdens mijn verblijf aan de Universiteit van Tilburg. De tweede persoon die niet ongenoemd mag blijven is Jaap de Hullu. Beste Jaap, ik ervaar het nog steeds als een groot genoegen om jouw mooie boek over het materiële strafrecht open te slaan en te genieten van beschouwingen over de verschillende facetten van strafrechtelijke aansprakelijkheid. 
Leden van de capaciteitsgroep Strafrecht en Criminologie, ik dank jullie voor de prettige ontvangst na mijn aanstelling en het verblijf in jullie midden. Mijn lidmaatschap van het OM staat niet in de weg aan een goede samenwerking in een omgeving waarin in het onderzoek en het onderwijs de positie van de verdediging een centraal aandachtspunt is.

De collega's van het OM in het ressortsparket dank ik voor de mij vergunde ruimte en vrijheid om mijn werk als advocaat-generaal en als bijzonder hoogleraar aan deze universiteit te kunnen combineren. De kruisbestuiving tussen het dagelijkse werk in de praktijk en in de spreekwoordelijke ivoren toren van de universiteit ervaar ik als inspirerend en verrijkend. Ik hoop dat de vruchten van dit werk ook jullie enig profijt oplevert, zodat ik daarmee de door jullie aan mij verleende gunsten enigszins kan compenseren.

Dames en heren studenten, ik ervaar het als een genoegen om bij gelegenheid van de uiteenlopende onderwijsactiviteiten met $u$ van gedachten te kunnen wisselen over het strafprocesrecht en de positie van het Openbaar Ministerie.

Beste familie en vrienden, werk is belangrijk om een goed leven te kunnen leiden. Dat goede leven wordt voor een wezenlijk deel door jullie geleverd. Ik geniet van de contacten aan de eettafel met een goed glas wijn, het geploeter op de tennisbaan, familiebijeenkomsten en wat dies meer zij. Ik dank jullie voor de warmte en vriendschap.

Mijn lieve Ans: mijn dank voor onze al lange en hopelijk nog lange gezamenlijke wandel door het leven is onuitsprekelijk. Ik hoop dat wij nog lang mogen genieten van onze dochters Laura en Renate, schoonzoon Guido en kleinzoon Max.

In deze zaal mis ik twee personen die ik hier graag had gezien, maar waarover het noodlot anders heeft beslist: mijn lieve moeder en mijn zusje Sandra. Aan hen is deze oratie opgedragen.

Ik heb gezegd. 
